\title{
Assessing the State of the Pelagic Habitat: A Case Study of Plankton and Its Environment in the Western Irish Sea
}

\section{OPEN ACCESS}

Edited by:

Alberto Basset,

University of Salento, Italy

Reviewed by:

Alexander Tzetlin,

Moscow State University, Russia

Marco Uttieri,

Parthenope University of Naples, Italy

*Correspondence: Cordula Scherer

cscherer@tcd.ie

Specialty section: This article was submitted to Marine Ecosystem Ecology, a section of the journal Frontiers in Marine Science

Received: 31 July 2016 Accepted: 01 November 2016 Published: 28 November 2016

Citation:

Scherer C, Gowen RJ and Tett P (2016) Assessing the State of the Pelagic Habitat: A Case Study of Plankton and Its Environment in the Western Irish Sea.

Front. Mar. Sci. 3:236. doi: 10.3389/fmars.2016.00236

\author{
Cordula Scherer ${ }^{1,2,3 *}$, Richard J. Gowen ${ }^{1,2}$ and Paul Tett ${ }^{2}$ \\ ${ }^{1}$ Fisheries and Aquatic Ecosystems Branch, Agri-Food and Biosciences Institute, Belfast, UK, ${ }^{2}$ Scottish Association of \\ Marine Science, Scottish Marine Institute, Oban Argyll, UK, ${ }^{3}$ Department of Zoology, Trinity College Dublin, Dublin, Ireland
}

Much work had been undertaken on tracking change in the condition of marine pelagic ecosystems and on identifying regime shifts. However, it is also necessary to relate change to states of good ecosystem health or what the European Marine Strategy Framework Directive (MSFD) calls "Good Environmental Status" (GES). Drawing on existing scientific and legislative principles, including those of OSPAR's "Strategy to Combat Eutrophication," we propose a framework for assessing the status of what the MSFD calls the "pelagic habitat" in temperate coastal seas. The framework uses knowledge of local ecohydrodynamic conditions, especially those relating to the stratification and optical environment, to guide expectations of what would be recognized as healthy in terms of ecosystem "organization" and "vigor." We apply this framework to the seasonally stratified regime of the Western Irish Sea, drawing on published and new work on stratification, nutrient, and phytoplankton seasonal cycles, zooplankton, and the implications of plankton community structure and production for higher trophic levels. We conclude that, despite human pressures including nutrient enrichment, and the food-web effects of fisheries, the pelagic ecosystem here is in GES, and hence may be used as a reference for the "Plankton Index" method of tracking change in state space in seasonally stratified waters.

Keywords: pelagic habitat, ecosystem assessment, reference conditions, ecohydrodynamics, Irish Sea, lifeforms, MSFD

\section{INTRODUCTION}

The Marine Strategy Framework Directive (2008) is the most recent European Union legislation designed to safeguard the environment and ensure the sustainable use of ecosystem services in marine waters within the exclusive economic zone of EU member states. Article 1 of the Directive states that the overarching aim is: "to achieve or maintain good environmental status in the marine environment by 2020 at the latest." There is thus an urgent practical need for EU member states to decide whether coastal seas are at this status. The Directive expands its definition of Good Environmental Status (GES) by means of 11 "Qualitative Descriptors" and a European Commission document (Commission Decision 2010/477/EU, 2010) provides assessment criteria for each descriptor. Four of these descriptors relate to the "pelagic habitat." Commission Decision 2010/477/EU (2010) defines habitat as "the abiotic characteristics and the associated biological community, treating both elements together in the sense 
of the term biotope," and makes clear that these provide the environmental conditions for species and functional groups at higher trophic levels. Thus, we understand the condition of the "pelagic habitat" as including the physical and chemical characteristics of the sea-water and the biological and ecological characteristics of the plankton found in that water: in effect, as a sub-system within a specified marine ecosystem.

How can the condition of components of marine ecosystems such as the pelagic habitat be assessed? Much literature describes the tracking of change in ecosystem state, often using multivariate methods (e.g., Edwards et al., 2006; Kenny et al., 2009; Spencer et al., 2011). Tett et al. (2013) proposed a framework for examining changes in the community organization and vigor of marine ecosystems by plotting trajectories in ecosystem state space and Tett et al. (2007, 2008) and Gowen et al. (2015) demonstrated a method (the "Plankton Index," PI) for calculating such trajectories for phytoplankton communities. These methods, however, can only provide estimates of change relative to an arbitrary starting point. The purpose of this paper is to propose a method to establish whether a spatially defined marine pelagic habitat is in GES. If the answer is yes, the aim is to replace the arbitrary starting point with a reference condition in GES giving change away from this state a more substantial meaning.

The method is intended to be of general applicability to the pelagic habitat in temperate shelf seas, since the science that underpins the normative components of the MSFD is relevant everywhere; we exemplify it here with an application to the Western Irish Sea (WIS; Figure 2). The specific objectives are to: (i) Set out the framework for assessment; (ii) Apply the framework to the WIS using existing and new data; (iii) Critic the framework in the light of the results.

\section{ASSESSMENT THEORY \\ Legal-Scientific Background}

The main policy driver of this study is the Marine Strategy Framework Directive (2008) and its aim of achieving GES especially in the qualitative descriptors Biodiversity, Foodwebs, the relevant part of Eutrophication and Seabed Integrity. Earlier Directives of relevance include the Urban Waste Water Treatment Directive (UWWTD: 91/271/EC) and the Water Framework Directive (WFD, 2000), which aims to bring "water bodies" to "Good Ecological Status."

The WFD requires the identification of a "type-specific reference condition" for each type of water body. These are defined (see Appendix V in WFD) as the values of hydromorphological, physico-chemical and biological quality elements under undisturbed conditions-i.e., where there is minimum anthropogenic alteration. If such conditions could be identified, they would provide an objective state from which change could be measured. However, this has proven problematic for WFD coastal water types (Bald et al., 2005; Borja et al., 2012). Reasons include the difficulty of finding undisturbed coastal waters and the dynamic nature of marine ecosystems. For example, Devlin et al. (2009) only had data from one non-impacted site to provide reference conditions for phytoplankton in six UK coastal water types.

The MSFD takes a broader view, Article 3.5 defines "Good Environmental Status" as (in part) where "the structure, functions, and processes of the constituent marine ecosystems, together with the associated physiographic, geographic, geological and climatic factors, allow those ecosystems to function fully and to maintain their resilience to human-induced environmental change." It has been argued (Tett et al., 2013) that fully-functioning and resilient ecosystems can be found even where there is human impact.

We equate MSFD pelagic GES with a state of good ecosystem health (Tett et al., 2013) and an absence of "undesirable disturbance" (Tett et al., 2007). Some changes from the zeropressure state cannot automatically be seen as detracting from GES: for example, a pelagic ecosystem might be fully-functioning at a level of production enhanced by moderate nutrient enrichment.

Finally, the MSFD's definition of GES includes the condition that human use of ecosystems is sustainable. Most ecosystem biological services are provided by high trophic levels and are outside the topic of the present paper. Nevertheless, a part of our assessment of the pelagic habitat lies in showing that it provides an adequate environment for commercial fisheries and protected marine vertebrates.

\section{Scientific Background}

The MSFD draws on scientific understanding to define GES as the condition of a fully functioning ecosystem, resilient to anthropogenic activity, and in which "diverse biological components function in balance." Ecologists hold a range of views about ecosystems and their holistic properties (Tett et al., 2013). Here, we interpret the concept ecosystem, using General Systems Theory (Von Bertalanffy, 1972), as referring to a bounded open system. Resilience is the system's ability to resist or recover from disturbance and is a property that emerges from ecosystem organization and vigor (Costanza, 1992; Mageau et al., 1995; Costanza and Mageau, 1999). Production is a component of vigor, and excess corresponds to eutrophication and may lead to undesirable disturbance. Conversely, lack of vigor constrains a system's abilities to respond to pressure. Organization is defined as "the types and arrangements or interconnections of the components of a system" (Tett et al., 2013), with the relevant components of ecosystems being functional groups. The pelagic habitat is a sub-system within a marine ecosystem, its functional groups are the main lifeforms of plankton, and its vigor depends on primary production and its coupling to higher trophic levels. Thus, assessment of plankton and its environment needs to consider both vigor and organization.

Although, the MSFD requires ecosystem assessment at the level of large marine sub-regions, the sea is oceanographically heterogenous at this scale. The Directive refers to "associated physiographic, geographic, geological, and climatic factors," which are expected to determine marine ecosystem structure and function. In the case of terrestrial environments, biome theory relates characteristic lifeforms of primary producers to climatic and geomorphological conditions (Clements, 1916; Woodward 
et al., 2004). The equivalent theory for marine systems is that of ecohydrodynamics (Tett et al., 2007), a term introduced by Nihoul (1981) to emphasize the interaction between hydrodynamic and ecological processes. Hydrodynamic processes such as turbulent mixing and seasonal stratification characterize the physical dynamics of water bodies in which phytoplankters live and to which species are adapted (Margalef, 1978; Pingree et al., 1978; Bowman et al., 1981; Jones and Gowen, 1990). Regional differences in zooplankton result in part from the seasonal patterns of phytoplankton production and hydrodynamic conditions (Backhaus et al., 1994; Dickey-Collas et al., 1996a; Fromentin and Planque, 1996; Gowen et al., 1998a). Parsons (1979), Cushing (1989), and Legendre and Rassoulzadegan (1995) consider how such differences in phytoplankton and zooplankton might combine into distinctive food-webs.

Defining an ecohydrodynamic type is, therefore, the first step in establishing environmental status, because it provides a basis for what is to be expected in a fully-functioning ecosystem of a given type. Van Leeuwen et al. (2015) used 50-year hindcasts with GETM-ERSEM to map persistent ecohydrodynamic regimes in the North Sea (Table 1). Their definitions of regimes, based on the reliable duration of stratification, provides a basis for (i) establishing homogenous marine areas for the purposes of our scheme, and (ii) identifying the ecohydrodynamic type of such areas. There are several ways to define stratification (e.g., Simpson et al., 1978): we follow the method described by Van Leeuwen et al. (2015) using surface-bottom density difference.

Finally, plankton communities are highly dynamic (Gowen et al., 2013). We see seasonal variation in plankton lifeforms as a key part of pelagic ecosystem organization and the analog of succession leading to climax communities in terrestrial ecosystems. In temperate latitudes the seasonal pattern of primary producer biomass and succession is ultimately driven by the annual cycle of illumination and, in some cases an annual cycle of stratification and mixing. The seasonal pattern of zooplankton consumers is largely driven by the producer cycle. Both are perturbed by other factors such as weather, local physical processes, and chaotic dynamics which creates "noise" in the "signal" of the seasonal pattern. Any assessment of the state of the plankton needs to distinguish the two.

\section{Assessment Methodologies}

Commission Decision 2010/477/EU (2010) provides criteria and operational indicators for the determination of GES. However, the development of appropriate thresholds for these indicators, and rules for aggregating them, is proving challenging (Ojaveer and Eero, 2011; Borja et al., 2012, 2014). There is something of a logical conundrum: waters of known GES are needed to calibrate the indicators, so the indicators themselves cannot be used to assess GES.

Reviewing the difficulties encountered during WFD implementation might be helpful. The first two relevant steps proved straightforward, but it is the third step that bore problems. The first two steps correspond, in our approach, to the delineation of sea-areas of single ecohydrodynamic type that is to: (1) Identify water-bodies, defined as: " $a$ discrete and significant element of surface water such as a lake... or a stretch of coastal water"; (2) Develop a typology for these water-bodies. We understand this delineation, also, as part of the typing and mapping of habitats required by Commission Decision 2010/477/EU (2010) for MSFD descriptor Biodiversity at the habitat level. The third step is more problematic since it requires the establishment of type specific reference conditions for each type. The WFD (Annex II.1.3) defines these conditions as corresponding to expectation for undisturbed conditions, and, although not stated explicitly in the Directive, it is understood that "undisturbed" means absence of significant endogenous pressures (Elliott, 2011). The Directive states that

TABLE 1 | Criteria for ecohydrodynamic regimes and identification of stratification regimes; Definitions used by Van Leeuwen et al. (2015) to map stratification regimes in a 50-year hind-cast with GETM.

\begin{tabular}{|c|c|c|c|c|c|}
\hline \multirow[b]{2}{*}{ Regime } & \multicolumn{3}{|c|}{ Duration (days per year) of: } & \multicolumn{2}{|c|}{ Proportion (\%) of days with CTD profiles that are: } \\
\hline & $\begin{array}{l}\text { Main period(s) of } \\
\text { stratification }\end{array}$ & $\begin{array}{c}\text { Main period(s) of } \\
\text { mixing }\end{array}$ & $\begin{array}{c}\text { Stratification- } \\
\text { mixing cycle }\end{array}$ & Stratified & Mixed \\
\hline Permanently stratified (PS) & $>345$ & $<20$ & 365 & $>95$ & $<5$ \\
\hline Seasonally stratified (SS) ${ }^{b}$ & $>120$ & $>90$ & 365 & $>33$ & $>25$ \\
\hline Permanently mixed $(\mathrm{PM})^{\mathrm{b}}$ & $<20$ & $>345$ & 365 & $<5$ & $>95$ \\
\hline $\mathrm{ROFIC}$ & $>3$ & $>3$ & $<120$ & $>25$ & $>25$ \\
\hline Intermittently stratified (IS) ${ }^{\mathrm{d}}$ & $<40$ & $\epsilon[120,250]$ & & & \\
\hline Indeterminate $e^{e}$ & & & & & \\
\hline
\end{tabular}

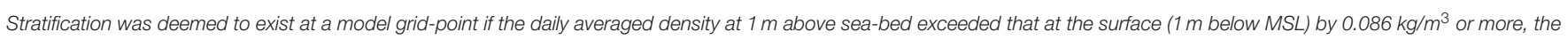
equivalent of an $0.5^{\circ} \mathrm{C}$ excess in the upper layer of a thermally stratified column averaging $10^{\circ} \mathrm{C}$ temperature at a salinity of 34.5. PSU (Levitus, 1982 ).

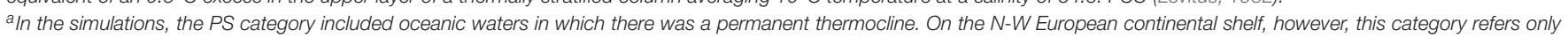
to waters that are haline stratified.

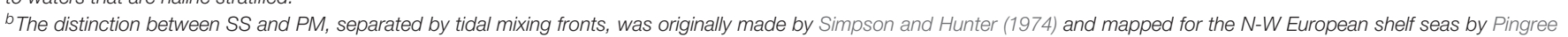
and Griffiths (1978).

${ }^{c}$ ROFI refers to "Regions of Freshwater Influence" (Simpson, 1997).

d"Intermittently stratified" (IS) applies to columns that van Leeuwen et al. classed as long-mixed conditions during winter time and repeated, short-lived thermal stratification in summer.

e "Indeterminate" could not be assigned to any category because there was no dominant regime. It refers to more than one of the above regimes depending on the year. 
identification of type-specific reference conditions "may be either spatially based or based on modeling, or may be derived using a combination of these methods. Where it is not possible to use these methods, Member States may use expert judgment to establish such conditions."

The spatially based procedure requires data for water bodies that are free of significant human pressures. It is possible to find sea-areas where there is little loading with anthropogenic nutrient (Halpern et al., 2008) even in North-West European shelf waters, but there are few, if any, where there is no fishing pressure (Lassen et al., 2013) with consequent disturbance of the sea-bed and the food-web (Kaiser et al., 2006; Thurstan et al., 2010). This does not mean that there are no areas at GES, only that it is not possible to use absence-of-pressure as the sole criterion to identify waters at GES.

Models that couple river catchments to regional seas have been used to identify reference conditions for coastal phytoplankton, by simulating reduced nutrient loading (Cugier et al., 2005; Lacroix et al., 2007; Lancelot et al., 2009), but full marine ecosystem models such as ERSEM (Blackford et al., 2004; Van der Molen et al., 2013) do not yet seem adequate to simulate, reliably, the impact of reduction of a range of pressures on the plankton as a whole.

Experts experience several difficulties in reaching objective conclusions. Baselines shift (Duarte et al., 2009): an expert's experience of the present-day world might only include ecosystems that an observer working in an earlier century might consider degraded. Expert groups may tend to a "lowest common denominator" consensus or be biased by a dominant point of view. Delphi procedures (Linstone and Turoff, 2002; Donohoe, 2011) can ameliorate the group difficulty, but are slow and expensive. An alternative is to challenge preliminary assessments with counter evidence, and to report the search for such evidence including that relating to conditions observed by earlier generations of observers. This is the approach we use here.

\section{Assessment Scheme for GES in the Pelagic Habitat}

Many of the methods reviewed in the literature on MSFD application, consider a piecewise approach to the assessment of GES, but this gives rise to challenges of aggregating indicators as well as the conundrum that calibrating indicators requires independent identification of waters at GES. We think that such identification requires a holistic rather than a piecemeal assessment, and that, at the current state of knowledge, a suitably controlled expert method is most likely to achieve this.

What the experts-in the case study, ourselves-are to be asked is: Does the pelagic habitat in a given water body correspond to expectation for a fully-functioning ecosystem component? We propose a 6-step approach: (1) Define the spatial location, extent, boundaries and context of the system under study; (2) Identify the system's ecohydrodynamic type in order to determine expectations for community vigor and organization; (3-4) Acquire data and analyse them in relation to vigor and organization; (5) Collate evidence relating to (lack of) anthropogenic pressure(s), and the functioning of higher trophic levels making use of the pelagic habitat; (6) Seek and take account of evidence that runs counter to conclusions from steps $3-5$ about status.

In order to structure the assessment and ensure that all available relevant information is taken into account, Table 2 provides a framework for steps 3-5. It is not intended as an algorithmic procedure, i.e., as a set of rules for arriving at an assessment, but as an agenda for a process of "communicative action" during which evidence and claims are recursively tested (Habermas, 1984). The table arranges items in a matrix in which the rows are the relevant MSFD qualitative descriptors and the columns relate to four aspects of the pelagic ecosystem. While this scheme is intended specifically for north-west European salt waters, it should be generally applicable and may be modified with locally-determined criteria where these are available.

Columns 3 and 4 of the table deal with ecosystem vigor. The column dealing with water chemistry mainly concerns concentrations of winter nutrients, for which thresholds for "non-problem areas" have been set by OSPAR COMMISSION (2003, 2005). Toxic pollution of water, which can impact on plankton, is not explicitly dealt with here (see MSFD QD8); its effects on community structure and function are picked up by other items in the table. Low sub-pycnocline oxygen concentrations can occur naturally in certain stratification regimes (see Gade and Edwards, 1980). The question is whether depletion has been enhanced by additional organic sedimentation from anthropogenic activity.

The "function" column corresponds more closely to vigor: there should be sufficient phytoplankton biomass and primary production to support a food web that is in "balance," but not so much that production is out of balance with consumption. In relation to the Food-webs descriptor of the MSFD, the goal for a "fully functioning" plankton community is that nutrient supplies are adequate to support expected plankton biomass and production; this sets a lower threshold, as distinct from the upper thresholds. The identification of appropriate minima has been little discussed. In principle, we want primary production to exceed a certain minimum value. In the absence of measured production, it should be possible to estimate this, using relationships between spot measurements of primary production and chlorophyll (Joint and Pomroy, 1993; Gowen and Bloomfield, 1996; Capuzzo et al., 2013). For Seabed integrity the goal for function is that meroplanktonic abundance is consistent with expectation and sufficient to renew the benthos.

Column 5, "structure," concerns, in principle, the "organization" component of Mageau et al. (1995): the pattern of (mainly trophic) relationships amongst plankters. We see this as highly dynamic at the species level (Gowen et al., 2012), naturally varying both inter-annually and seasonally, but always with a requirement for a dynamic balance of functional groups or "lifeforms." Assessment can thus be based on the relative seasonal patterns of microplankton lifeforms, such as the succession from diatoms to dinoflagellates expected in seasonally-stratifying temperate seas. The timing ("phenology") of events in the seasonal cycle is important, especially if it leads to mismatch between phytoplankton and zooplankton cycles, or between these and fish larval food needs (Cushing, 1969; Platt and Sathyendranath, 2008). Where data are available, it 


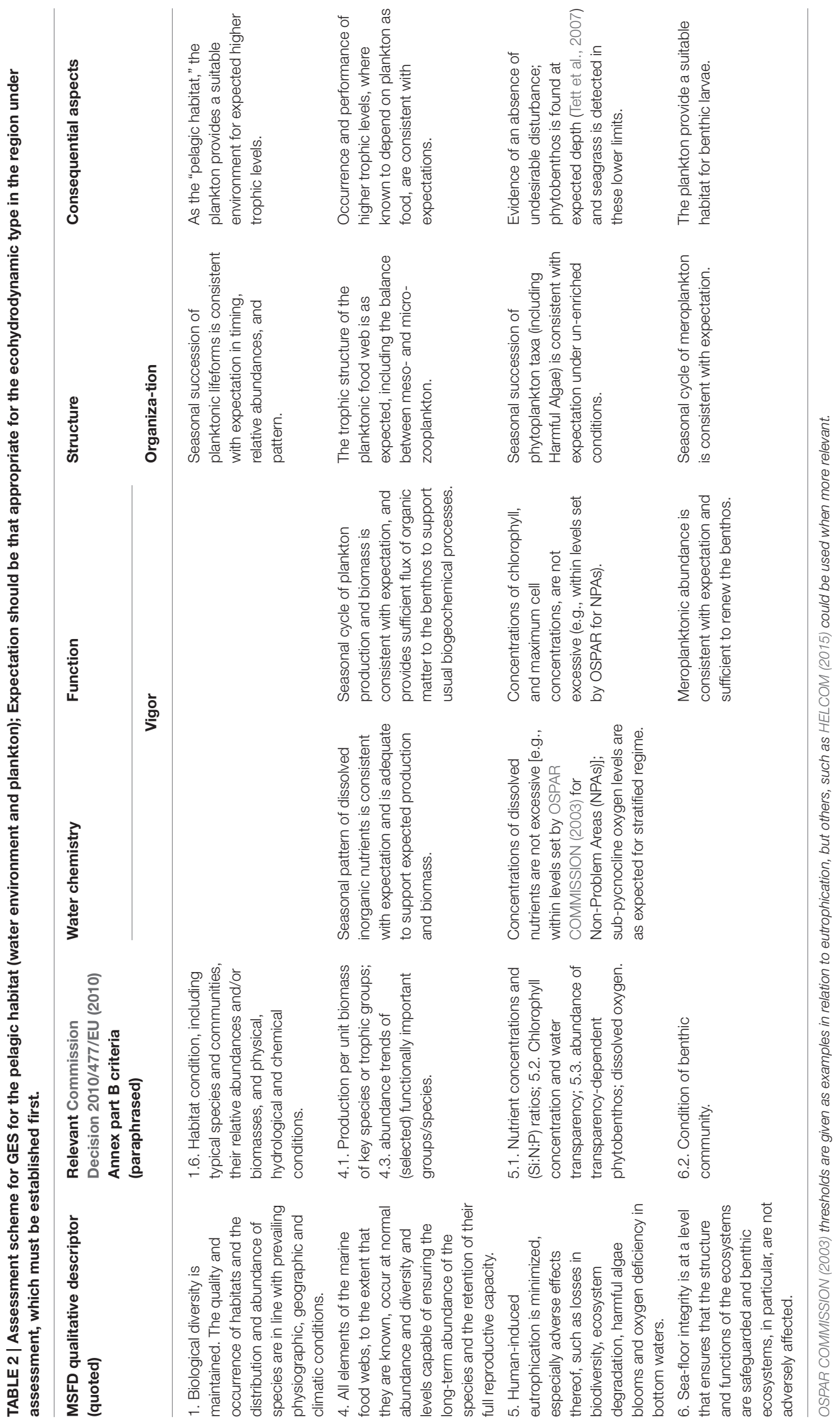


is desirable to consider a longer list of lifeforms, (e.g., small flagellates, coccolithophores, ciliates, and picoplankton). Finally, mesozooplankton-both holo- and mero- must be included in relation to Food-webs and Seabed Integrity.

The final column in Table 2 concerns the observed consequences of pressure-induced changes in the plankton for other parts of the marine ecosystem, which includes the benthos and higher trophic levels of the pelagic system such as fish and birds. There are three points to consider here. First, does the plankton provide food for the higher trophic levels that would be expected in a fully functioning system? Are the biota of the higher trophic levels present as expected, or, if less or more abundant than expected, can this be traced to food supplies, as has been claimed for kittiwakes (Frederiksen et al., 2004; Wanless et al., 2007)? Second, is there any evidence of an "undesirable disturbance." This needs to be considered from both top-down pressure (resulting from fisheries as claimed for the Baltic Sea, Österblom et al., 2007) and bottom-up pressure (nutrient enrichment, Tett et al., 2007). Third, is there any evidence that the pelagic ecosystem is resilient to anthropogenic pressures? The latter requires time series of organization, vigor, and pressures.

\section{Expectations and Climatologies}

Assessment requires a comparison between the observed state of the pelagic ecosystem and its expected state given the physical conditions-i.e., given a particular ecohydrodynamic type. A conceptual model (Figure 1) is useful in considering expectation. According to this model, the main driver of the state of the pelagic ecosystem is the astronomical cycle that gives rise to temperate-latitude seasonal cycle of illumination and heating. The illumination cycle is the direct driver of primary production, and the heating cycle drives not only water temperature and directly affects vigor, but more importantly, changes in thermal stratification. This seasonal cycle is the oceanographic "signal." It is confused by "noise," i.e., short-term variation that results from weather, local oceanographic processes, and ecosystem dynamics. The physical signal plus noise then gives rise to seasonality in the chemical and biological dynamics of the pelagic habitat and comparison of observed and expected state needs to consider the generalized seasonal biological signal whilst taking account of the noise.

The main way to distinguish signal from noise is to extract statistics of seasonal variation from several years of data, the argument being that the noise is essentially random and hence that an average pattern will tend toward the true cycle as the random component sums to zero. The signal may evolve because of climate change but can be treated as constant in the medium term.

A picture of the mean seasonal cycle, with information on the variability about that cycle, is widely called "climatology" (after the usage of Levitus, 1982). It is the mean cycle that can be compared with biological expectation, since the expectation in principle derives from the astronomical driver by way of hydrodynamics, while the variability provides a basis for assessing whether there is a significant difference between expected and observed climatologies.

\section{THE WESTERN IRISH SEA}

The Irish Sea (Figure 2) lies on the north-western European continental shelf between the islands of Britain and Ireland, and is part of the MSFD "Celtic Seas" marine sub-region. Much of it is less than $50 \mathrm{~m}$ deep, although there is a trough $\sim 100 \mathrm{~m}$ deep to the south-west of the Isle of Man and more than $200 \mathrm{~m}$ deep in parts of the North Channel between Scotland and Ireland. The sea is economically important for fisheries and is also a source of fossil and renewable energy.

Study of Irish Sea hydrography and plankton commenced at the beginning of the twentieth century (Bassett, 1909; Matthews, 1914; Herdman, 1918). It became apparent that Atlantic seawater reaches the Irish Sea via the Celtic Sea and St. Georges Channel. The predominant flow is northwards with a volume transport of $8.1 \mathrm{~km}^{3} \mathrm{~d}^{-1}$ across the southern entrance (Bowden, 1955). Dickson and Boelens (1988) estimated, based on the conservative salt and caesium-137 tracers, a net transport between 2 and 8 $\mathrm{km}^{3} \mathrm{~d}^{-1}$ into the Irish Sea through the North Channel from the Malin Shelf. Summer stratification of the WIS was first observed by Matthews (1914). The discovery of a thermal tidal mixing front south-west of the Isle of Man (IoM; Simpson and Hunter, 1974) led to confirmation that there is a region of seasonally stratifying water to the west of the IoM. During spring and summer a cyclonic gyre of near surface water becomes established in this part (White et al., 1988; Hill et al., 1994, 1997). The stratified region is a depositional area (Trimmer et al., 2003), and the seabed beneath it is mainly mud (Hensley, 1996). It is this stratified region, hereafter referred to as the WIS that is the subject of our case study.

\section{METHODS FOR CASE STUDY}

\section{General}

Since the early 1990s, regular surveys of the oceanography, nutrients, and plankton of the WIS have been undertaken by the Department of Agriculture and Rural Development (DARD), subsequently the Agri-Food and Biosciences Institute (AFBI) in Northern Ireland. An instrumented mooring was deployed in 1995 at $53^{\circ} 47.20^{\prime} \mathrm{N} 05^{\circ} 37.75^{\prime} \mathrm{W}$ (station 38 ) in a water depth of $105 \mathrm{~m}$. In 1997, the mooring was moved to $53^{\circ} 47^{\prime} 0 \mathrm{~N}$ and $05^{\circ} 38^{\prime} 0$ $\mathrm{W}$ (station 38A) at a depth of $94 \mathrm{~m}$ (Figure 2). The mooring was equipped with a CTD instrument, remote access water samplers for nutrients (RAS-100) and phytoplankton (RAS-500) and a surface-bottom string of thermistors. We draw on published and unpublished data from these surveys and the instrumented moorings for our analysis (see Table 3 for details and source references).

\section{Ecohydrodynamics}

CTD profiles obtained from research vessel visits to station 38 and 38A were analyzed according to the criteria in Table 1 with stratification deduced from differences between near-surface and near-bed density. The effect of salinity alone was calculated using temperature averaged over the two depths. The thermally-defined surface mixed layer (th-SML) was defined as extending to the 


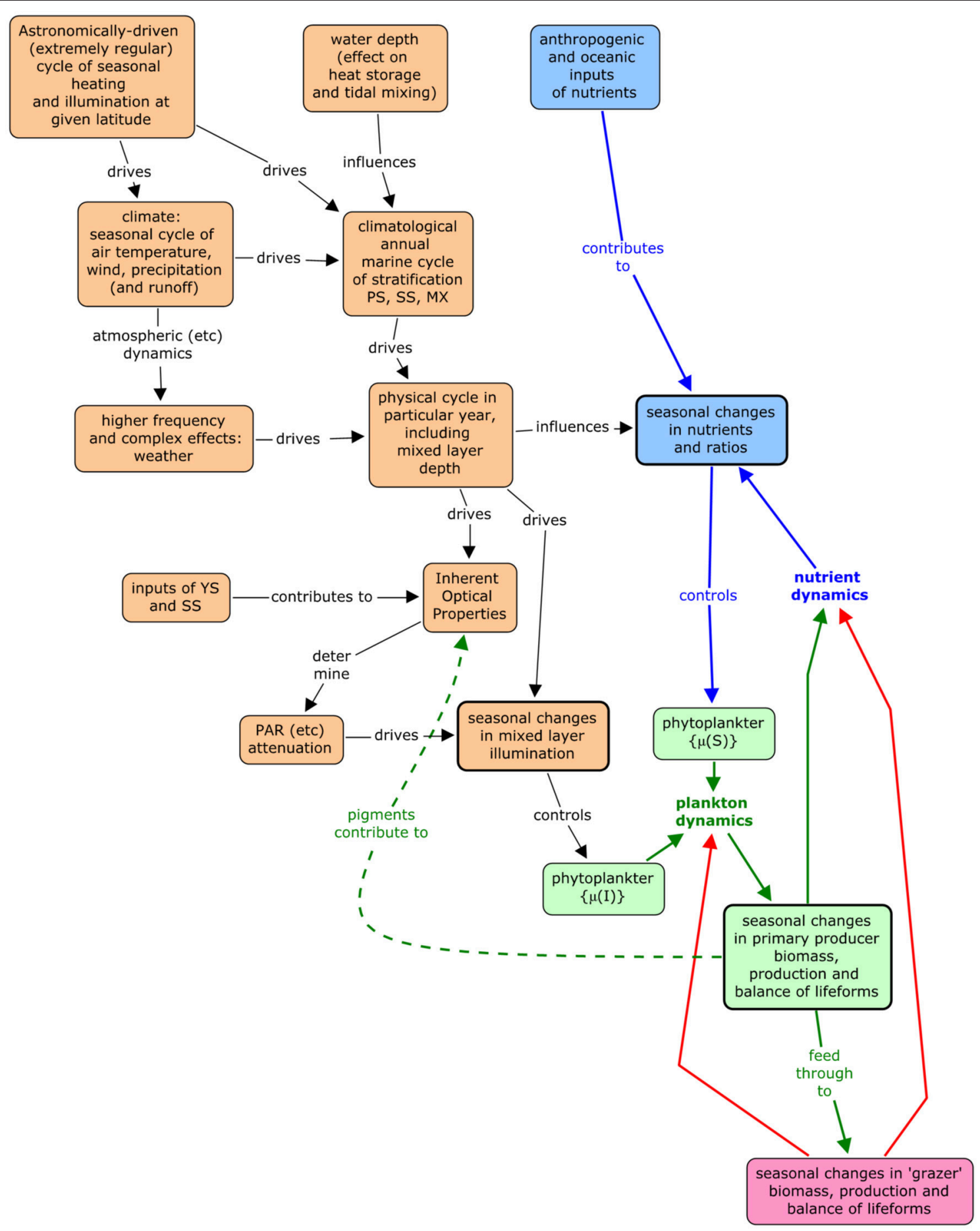

FIGURE 1 | Conceptual model of the relationship between abiotic processes and pelagic ecosystem vigor and organization.

depth $h_{m}$ at which water temperature was $0.5^{\circ} \mathrm{C}$ less than that at $2 \mathrm{~m}$ (Talling, 1971).

Euphotic zone depth was calculated from $k_{D}$ in two ways (Table 3). For data retrieved before 2002, $k_{D}$ was calculated from submarine PAR measurements from depths greater than $1 \mathrm{~m}$ optical thickness (Gowen et al., 1995, 2000; Gowen and
Bloomfield, 1996). For 2002-2012 values for $k_{D}$ were taken from remote sensing (Capuzzo et al., 2013). The empirical OC5 algorithm for optically-complex (Case-II) waters was used to retrieve the water column components from ocean color (Gohin et al., 2002). Daily values of $k_{D}$ (PAR) for this case study were extracted from the daily maps. 


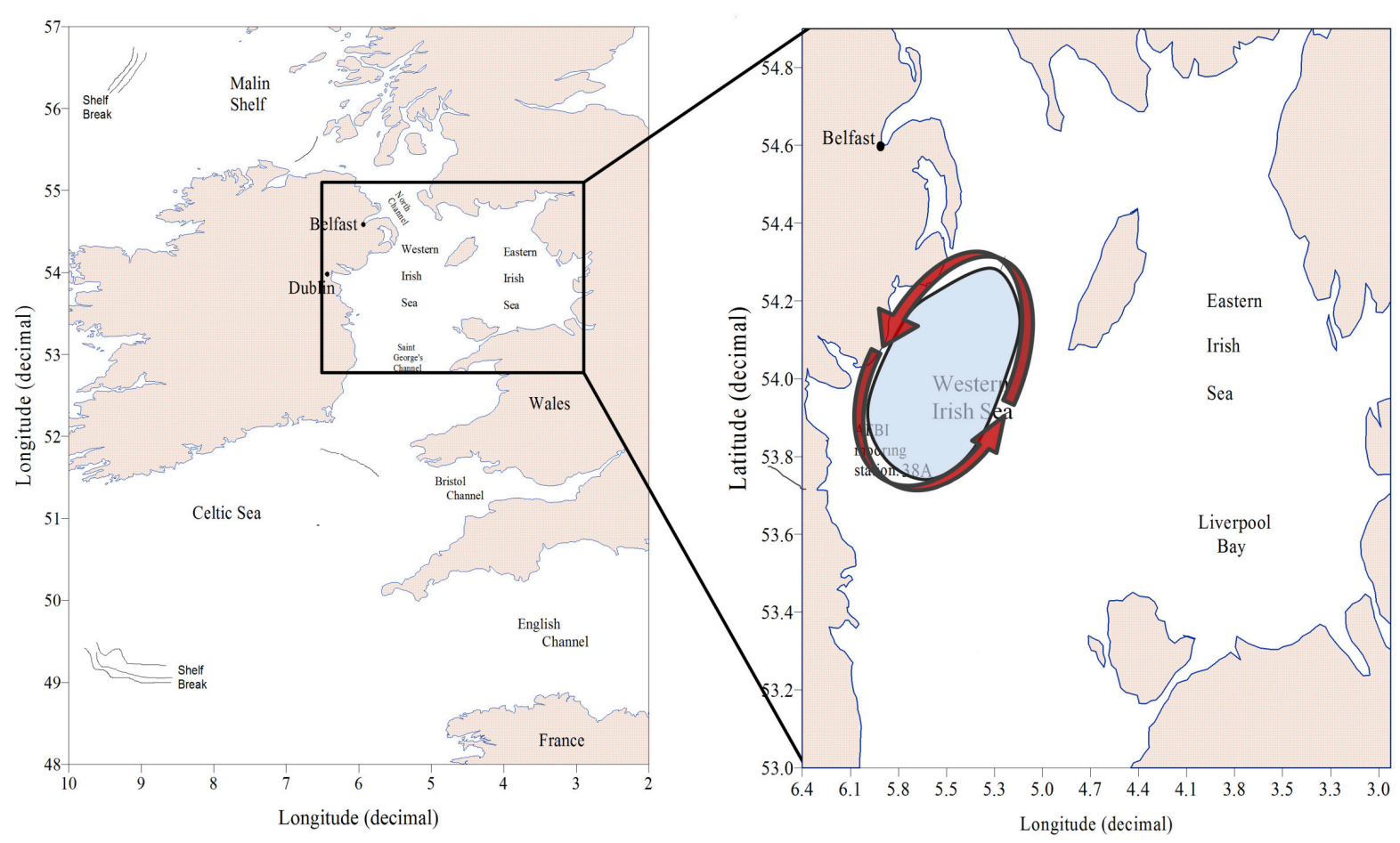

FIGURE 2 | Map of the case study showing the location of the Western Irish Sea, the AFBI mooring station 38A and a cartoon (Hill et al., 2008) illustrating the seasonal cyclic gyre that establishes during spring over the Western Irish Sea (WIS).

TABLE 3 | Summary of methods; methods used for analysis of data mainly derived from AFBI core monitoring programs and from EFF-funded surveys in 2013.

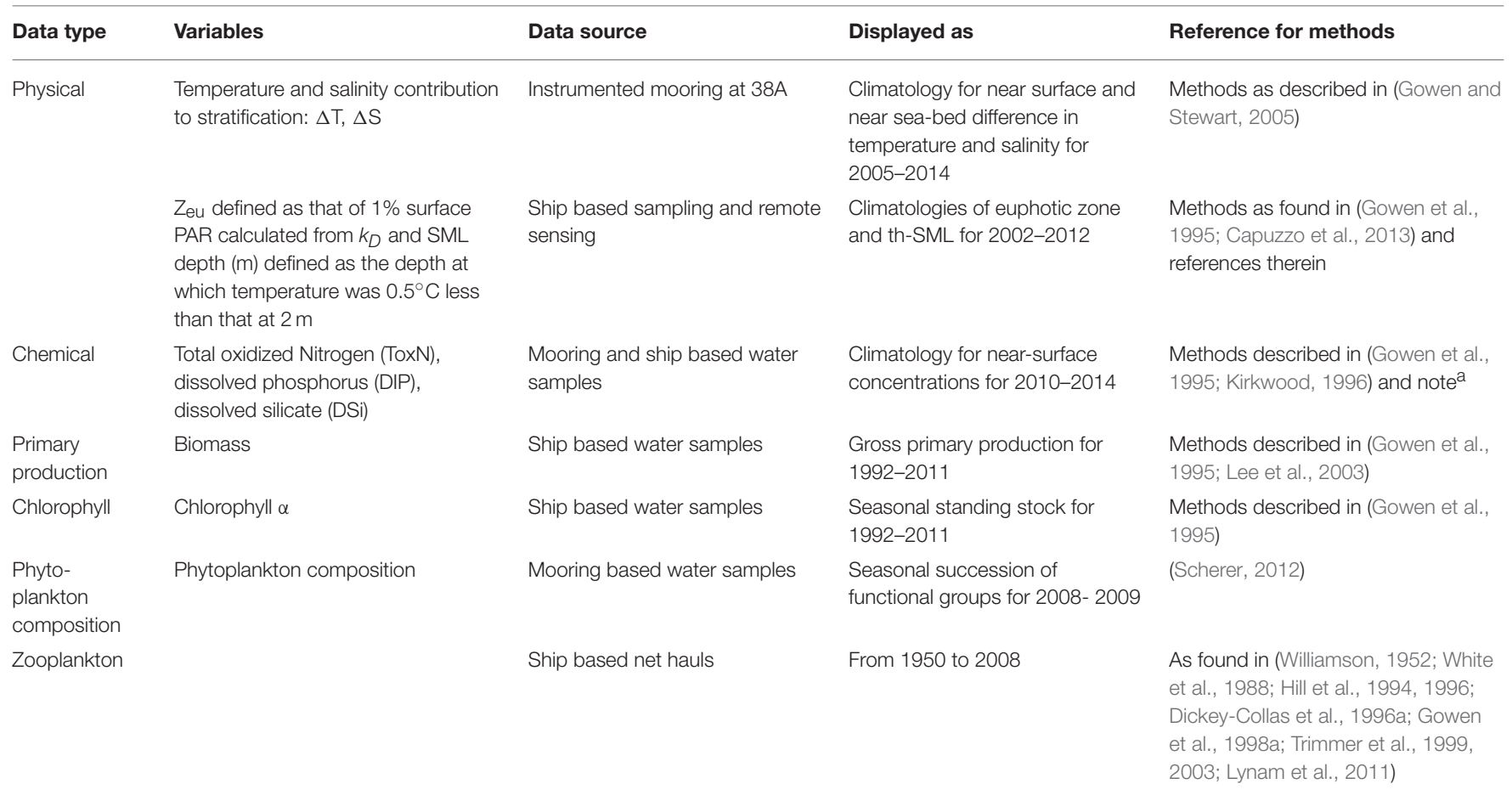

a Up to 2008 water samples for nutrient analysis were pre-fixed with mercuric chloride, since then this step was replaced by freezing $\left(-20^{\circ} \mathrm{C}\right)$ water samples immediately after collection until analysis. 
TABLE 4 | Functional groups of plankton defined for the present study of the WIS.

\begin{tabular}{|c|c|c|c|}
\hline & Functional Group & Description and WIS Examples & Pub. data sources for WIS \\
\hline \multicolumn{4}{|l|}{ MICROPLANKTON } \\
\hline \multirow[t]{3}{*}{ Photoautotrophs } & Diatoms (small) & $\begin{array}{l}\text { Si-requiring; cells <20 } \mu \mathrm{m} \text { total length; Skeletonema, } \\
\text { Thalassiosira, Chaetoceros, Guinardia }\end{array}$ & $\begin{array}{l}\text { Williamson, 1952; McKinney et al., 1997; Gowen } \\
\text { et al., 1999, 2012; Scherer, } 2012\end{array}$ \\
\hline & Diatoms (large) & $\begin{array}{l}\text { Si-requiring; cells > } 20 \mu \mathrm{m} \text { total length; Rhizosolenia, Guinardia, } \\
\text { Thalassiosira, Coscinodiscus }\end{array}$ & $\begin{array}{l}\text { Williamson, 1952; McKinney et al., 1997; Gowen } \\
\text { et al., 1999, 2012; Scherer, } 2012\end{array}$ \\
\hline & Silico-flagellates & Si-requiring; Dictyocha & Ditto \\
\hline \multirow[t]{2}{*}{ (inc. myxotrophs) } & Dino-flagellates (small) & $\begin{array}{l}\text { Cells }<40 \mu \mathrm{m} \text { total length: Scrippsiella, gonyaulacoids, } \\
\text { Prorocentrum, }\end{array}$ & Ditto \\
\hline & Dino-flagellates (large) & Cells $>40 \mu \mathrm{m}$ total length: Ceratium Dinophysis, Karenia & Ditto \\
\hline All nutritional types & Flagellates (small) & $\begin{array}{l}\text { Cells <10 } \mu \mathrm{m} \text { : zooflagellates (feeding on bacteria and } \\
\text { picocyanobacteria), zoospores, and phytoflagellates (including } \\
\text { prymnesiophytes, cryptophytes...) }\end{array}$ & Scherer, 2012 \\
\hline \multirow[t]{2}{*}{ Heterotrophs } & Ciliates (oligotrichs) & $\begin{array}{l}\text { Class Spirotrichea, subclass Choreotrichia (in the classification of } \\
\text { Lynn, 2003): Laboaea, Strombidium, tintinnids; filter feeders } \\
\text { Kiørboe, } 2011 \text { on bacteria and small micro-algae (smaller than } \\
\text { ciliates) }\end{array}$ & Scherer, 2012 \\
\hline & Dino-flagellates & $\begin{array}{l}\text { Gyrodinium, Protoperidinium; raptorial feeding on other protoctists } \\
\text { by tube, pallium, or engulfment (Hansen and Calado, 1999); prey } \\
\text { same order of magnitude in size }\end{array}$ & Scherer, 2012 \\
\hline \multicolumn{4}{|c|}{ ZOOPLANKTON: ANIMALS } \\
\hline & Copepods (small) & $\begin{array}{l}<1.5 \text { mm as adults; including copepodites; Acartia (3), Temora (4), } \\
\text { Oithona (5), Pseudocalanus (6), where the numbers are the } \\
\text { "functional groups" of Benedetti et al. (2015) who classify them all } \\
\text { as "nonpredators," i.e., as feeders (in various ways) on } \\
\text { protoctistan microplankton of detritus; seasonal succession } \\
\text { Pseudocalanus to Acartia in WIS }\end{array}$ & $\begin{array}{l}\text { Scrope-Howe and Jones, 1985; Gowen et al., } \\
\text { 1998a, } 1999\end{array}$ \\
\hline & Copepods (large) & $\begin{array}{l}\text { > } 2.5 \mathrm{~mm} \text { as adults; including copepodites; Calanus (4), also } \\
\text { "nonpredators"; overwinter in deep water, so their seasonal cycle } \\
\text { as well as size distinguishes them from the other copepods }\end{array}$ & $\begin{array}{l}\text { As above, plus (Gowen et al., 1997; Nash and } \\
\text { Geffen, 2004) }\end{array}$ \\
\hline & Euphausiids & $\begin{array}{l}\text { Meganyctiphanes and their furcilia; classified as predators, i.e., } \\
\text { feeding on copepods when available, but also ingesting } \\
\text { microplankton and detritus }\end{array}$ & $\begin{array}{l}\text { Williamson, 1956; Armstrong, 1982; Mitson et al., } \\
1996\end{array}$ \\
\hline & Pelagic predators & Includes chaetognaths: Sagitta; and ctenophores: Pleurobrachia & Alvarez-Cadena, 1993; Dickey-Collas et al., 1996b \\
\hline & Scyphome-dusan jellies & $\begin{array}{l}\text { Pelagic predator, sexually reproducing stage of strobilating benthic } \\
\text { polyp and so linked to shallow seas where the polyp can grow: } \\
\text { Aurelia }\end{array}$ & Lynam et al., 2011; Bastian et al., 2014 \\
\hline & Mero-plankton & $\begin{array}{l}\text { Larvae of benthic invertebrates including molluscs, echinoderms } \\
\text { and annelids }\end{array}$ & Scrope-Howe and Jones, 1985 \\
\hline & Young of nekton & Fish larvae, Nephrops larvae-feeding type, seasonality & Conway et al., 1997 \\
\hline
\end{tabular}

\section{Nutrients, Oxygen, Chlorophyll, and Production}

Samples for analysis for dissolved inorganic nutrients, oxygen, and chlorophyll, were taken from water-bottles attached to a ship-deployed CTD system; nutrient samples were also taken by the automated sampler attached at a notional depth of $12 \mathrm{~m}$ to the instrumented mooring. Dissolved inorganic phosphate (DIP), dissolved inorganic oxidized nitrogen (ToxN, nitrite plus nitrate), and soluble silicate (DSi) were determined colorimetrically (Gowen and Stewart, 2005). Oxygen was determined by the Winkler method (Strickland and Parsons, 1968) and after 2008 an oxygen probe attached to the CTD instrument provided additional data. Chlorophyll was determined following the method by Tett (1987). Samples were filtered and either analyzed immediately or stored frozen $\left(-20^{\circ} \mathrm{C}\right)$ for later analysis on board the ship or in the laboratory.
Comparisons showed no significant differences between "fresh" and "frozen" samples (B. Stewart, AFBI, pers. com.). Chlorophyll

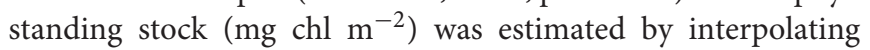
sampled values to $1 \mathrm{~m}$ intervals and summing over the euphotic zone (Gowen et al., 1995).

Primary production data are taken from Gowen et al. (1995) and Gowen and Bloomfield (1996). These authors used the ${ }^{14} \mathrm{C}$ tracer method (Strickland and Parsons, 1967) to estimate carbon assimilation, the method of Herman and Platt (1986) to calculate gross daily column production and the method of Joint and Pomroy (1993) to estimate daily column production from chlorophyll standing stock. For the purposes of this paper column daily net primary production was estimated by subtracting column respiration, $R^{\circ}$ according to Lee et al. (2003). New production during the period of the Spring Bloom was estimated by multiplying 
TABLE 5 | Summary of nutrient and chlorophyll data for the WIS.

\begin{tabular}{|c|c|c|c|c|c|}
\hline $\begin{array}{l}\text { Nutrient }(\mu \mathrm{M}) \text { (in } \\
\text { surface mixed layer) } \\
\text { and season (months) }\end{array}$ & $\begin{array}{l}\text { Means (and SD) of } \\
\text { monthly means in SML in } \\
2010-2014 \text { at } 38 A\end{array}$ & $\begin{array}{c}\text { Near/at/beyond shelf-break, } \\
49^{\circ} \mathrm{N}, \text { Jan-Feb in } 1994 \\
1998,1999^{\mathrm{a}}\end{array}$ & $\begin{array}{l}\text { OSPAR thresholds } \\
\text { for UK and ROI } \\
\text { offshore waters }\end{array}$ & $\begin{array}{l}\text { Irish Sea source } \\
\text { freshwater } \\
\text { concentration }^{a}\end{array}$ & Calculated for WIS ${ }^{a}$ \\
\hline Winter $(1 ; 2 ; 3)$ ToxN & $6.0(0.4) ; 7.0(0.8) ; 7.0(0.7)$ & 6.5-8.5; $8.0 @ 35.6$ & 15 & $146 @ 0$ & $13.0 @ 34.3$ \\
\hline Winter $(1 ; 2 ; 3)$ DIP & $\begin{array}{c}0.79(0.19) ; 0.68(0.05) \\
0.73(0.09)\end{array}$ & $0.5 @ 35.6$ & 0.8 & $12.8 @ 0$ & $0.95 @ 34.3$ \\
\hline Winter $(1 ; 2 ; 3) \mathrm{DSi}$ & 7.6 (0.7); 7.8 (0.5); $7.5(0.4)$ & 2.4-2.8; $2.3 @ 35.6$ & & $122 @ 0$ & $6.7 @ 34.3$ \\
\hline Summer (6) ToxN & $0.8(0.8)$ & & & & \\
\hline Summer (6) DIP & $0.47(0.42)$ & & & & \\
\hline Summer (6) DSi & $1.6(0.8)$ & & & & \\
\hline
\end{tabular}

\begin{tabular}{|c|c|c|c|}
\hline & & & $\begin{array}{c}\text { Redfield } \\
\text { [perturbation }^{\text {thresholds] }}\end{array}$ \\
\hline $\begin{array}{l}\text { Winter }(1 ; 2 ; 3) \text { dissolved } \\
\mathrm{N}: \mathrm{P} \text {, atomic (at):atomic } \\
\text { (at) ratio }\end{array}$ & $7.8(1.3) ; 10.3$ (1.1); 9.8 (1.5) & 16 & 16 (6 and 25) \\
\hline Winter (diss.) N:Si, at:at & 0.8 (0.1); $0.9(0.1) ; 0.9(0.1)$ & 3.5 & $1.0(0.5$ and 3$)$ \\
\hline $\begin{array}{l}\text { Chlorophyll (in SML) } \\
\text { and season } \\
\text { (month N) }\end{array}$ & $\begin{array}{l}\text { Mean values (1992-2011) } \\
\text { at station } 38 \text { (up to 1997) } \\
\text { and 38A (from 1997) }\end{array}$ & & $\begin{array}{l}\text { OSPAR thresholds } \\
\text { for UK and ROI } \\
\text { offshore waters }\end{array}$ \\
\hline
\end{tabular}

Spring (4-5) peak

column chl, $\mathrm{mg} \mathrm{m}^{-2}$

Mean post spring (6-9)

column chl, $\mathrm{mg} \mathrm{m}^{-2}$

Growing season (3-9)

mean SML chl conc,

$\mathrm{mg} \mathrm{m}^{-3}$

120

50

2

15

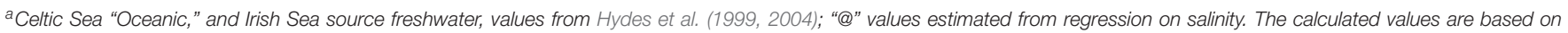
salt-freshwater mixing, using the Hydes values as end-members; 34.3 is the mean winter salinity in the WIS. The calculation is unreliable for phosphorus.

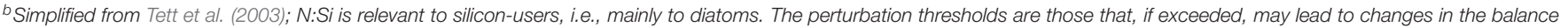
of phytoplankters: for example, N:Si too high selects against diatoms, N:P too low may select for N-fixing cyanobacteria.

the column draw-down of ToxN by the Redfield C:N ratio (Table 5).

\section{Plankton Sampling and Analysis}

The plankton was sampled in two ways during the DARD and AFBI studies. Micro-organisms were sampled by automatic sampler (McKinney et al., 1997) or rosette-water-sampler (Scherer, 2012) preserved in acidic Lugol's iodine, and enumerated using inverted visible-light microscopy after sedimentation (Utermöhl, 1958). Planktonic animals were sampled either by vertical hauls with 300 (Gowen et al., 1997) and $280 \mu \mathrm{m}$ mesh (Gowen et al., 1999) or by a double-oblique tow of a Gulf III sampler with a $280 \mu \mathrm{m}$ mesh net (DickeyCollas et al., 1996a). Catches were preserved with buffered $4 \%$ formaldehyde and volumetrically subsampled for analysis. Methods for jellyfish and "semi-nekton" such as fish larvae and euphausiids are given by Dickey-Collas et al. (1996a) and Lynam et al. (2011).

Plankters were identified to species whenever possible, otherwise qualified as high-level taxa with additional criterion such as size. The estimates of numerical abundance or biomass were aggregated into the lifeforms or functional groups listed in Table 4 (Scherer et al., 2014). The set of photoautotrophic lifeforms (including some myxotrophs) is referred to as phytoplankton; all micro-organism lifeforms (including ciliates, heterotrophic dinoflagellates, and phytoplankters) is referred to as "microplankton" (Scherer, 2012). The latter definition draws on the original sense of the term proposed by Dussart (1965) as distinct from the size range of phytoplankters defined by Sieburth et al. (1978) and Lalli and Parsons (1997).

\section{Climatologies}

Two methods were used to extract climatologies from the data. One was to compute means $\bar{y}(m)$ for each month $\mathrm{m}$ in the years chosen for analysis, and then to compute climatological monthly means $\overline{\bar{y}}(m)$ from these, so weighting each year equally. Variability was estimated from the standard deviation of the $\bar{y}(m)$. The second method, inspired by cyclical nature of the astronomical driver in the conceptual model (Figure 1), was to fit a truncated Fourier series with a base frequency of $1 \mathrm{yr}^{-1}$ (Brito et al., 2009). 
We used data collected between 1992 and 2014 which means some conclusions rely on comparisons of data taken across time: for example microplankton from 2008 to 2009 with copepods from 1992 to 1996. Changing global and regional climate, and changing anthropogenic pressures, might be expected to lead to decadal-scale changes in marine physical and biotic climates in the WIS. Therefore, only data previously examined for temporal trends (e.g., Allen et al., 1998; Gowen et al., 2002, 2008) were considered here using the Mann-Kendall non-parametric test for monotonic trends (Hirsch and Slack, 1984; Hirsch et al., 1991).

Seasons in temperate seas, although ultimately driven by the same astronomical processes responsible for terrestrial seasons, differ from the conventional seasons. We therefore refer to events or periods using the day of (a generalized) year. Table 8 brings these markers together in relation to named seasons relevant to the WIS ecohydrodynamic and biotic regimes.

\section{RESULTS AND FIRST-ORDER DISCUSSION}

\section{The Extent of the Study Region}

The extent of the WIS in Figure 2 was based on numerical simulations (Hill et al., 2008) with ample observational justification (Gowen et al., 1995; Horsburgh et al., 2000) of a seasonally stratified region extending around $60 \mathrm{~km}$ North-South and $40 \mathrm{~km}$ East-West. The mooring station 38A lies toward the southern end of this region.

Gowen et al. (1995) found that the exact region delineated by the potential energy anomaly (PEA, $\varphi$ ) contour varied between surveys. We assume that the deep muddy trough (Hill et al., 1994) corresponds to the long-term mean extent of the seasonallystratifying waters. The area of this patch is $\sim 3504 \mathrm{~km}^{2}$ and with an average depth of $90 \mathrm{~m}$ giving the WIS a volume of $\sim 3.15 \times$ $10^{11} \mathrm{~m}^{3}$.

\section{The Ecohydrodynamic Conditions}

Bowden (1950) reported the annual mean surface salinity for offshore waters in the WIS to be between 34.12 and 34.14 (recorded as \%o) for the period of 1903-1931. Gowen et al. (1995) gave the 1992 annual median as $34.17 \%$. For the last 10 years salinity has averaged 34.07 (psu) at station 38A, with a typical range of 0.53 between winter maxima and summer minima. Measurements of sub-surface $(5 \mathrm{~m})$ water temperature made between 1996 and 2013 show a pronounced seasonal cycle with winter minima of $7-8^{\circ} \mathrm{C}$ and a summer maxima $\sim 16^{\circ} \mathrm{C}$. These data establish the WIS as a euhaline and temperate water-body.

Thermal stratification typically begins end of April \pm 3 weeks (Bowden, 1955; Slinn, 1974; Gowen et al., 1995; Horsburgh et al., 2000). Although the deeper water is supposed to be isolated as a "cold pool" within the gyre circulation (Hill et al., 1997) it warms slowly during the summer explained in numerical simulations by advection from the north (Holt and Proctor, 2003). Salinity layering has often been observed from February through May (Figure 3) and Gowen et al. (1995) reported that this contributed to the onset of density layering in the WIS. Models (Holt and Proctor, 2003) suggest that the freshwater results from Irish runoff spreading over the winter's inflow of oceanic water from the Celtic Sea.

The salinity contribution to layering might be expected to allow earlier phytoplankton growth than would otherwise be the case. However, water in the Irish Sea, especially in the winter, contains higher loads of Suspended Particulate Matter (SPM; Coombes et al., 1994), than found in other seasonally stratified regimes such as those in the North Sea (Capuzzo et al., 2013). Smoothed monthly mean sub-surface PAR attenuation in 1992 and 1993 fell from $0.30 \mathrm{~m}^{-2}$ in March to $0.20 \mathrm{~m}^{-1}$ in JuneAugust but had increased to $0.25 \mathrm{~m}^{-1}$ in October (Gowen and Bloomfield, 1996). This is consistent with reports that SPM concentrations decrease in the Irish Sea during the season of stratification, as the material sinks below the pycnocline (Weeks and Simpson, 1990; Weeks et al., 1993).

Figure 4 shows euphotic zone depth estimated from remote sensing in 2002-2012 and th-SML thickness for 1992-1996 from Gowen et al. (1998b). According to this, the season during which stratification provides favorable conditions for photosynthesis is relatively short: 123 days (from day 124, May 3 to day 247, September 3).

\section{Nutrients and Oxygen}

Whereas, there is clear evidence (Gowen et al., 2002) of nutrient enrichment in Liverpool Bay, and Irish coastal waters, concentrations and seasonal cycles of ToxN and DSi have not changed in the WIS since first measurements in the mid 1950s to late 1960s by Slinn (1974) (Gowen et al., 2008). The median winter concentrations of DIP have decreased since 1989 (Gowen et al., 2008).

Recent data (Figure 5) for near-surface ToxN, DIP, and DSi show maxima in January/February $(7.0,0.8$, and $7.8 \mu \mathrm{m}$, respectively), followed by minima in June/July $(0.8,0.5$, and 1.6 $\mu \mathrm{m}$, respectively). Climatological near-surface ToxN fell to half of the winter maximum on day 121 (21 April) with a time range of \pm 3 weeks (30 March-23 May). Deep water concentrations remain high, close to winter values, with upwards losses probably replaced by deep-water and benthic mineralization of sinking organic matter, less denitrification (Trimmer et al., 1999; Gowen and Stewart, 2005).

WIS nutrient dynamics are still debated. Background diapycnal mixing seems weak, and the summer flux of nutrients that supports a midwater chlorophyll maximum may result mainly from event mixing (Williams et al., 2013). The initial summer increase in SML nutrients (Figure 5) seems correlated with SML deepening (Figure 4) and hence with entrainment of deeper water during August and September. The rest of the increase to the winter maxima has been variously ascribed to local remineralization (Gibson et al., 1997), freshwater nutrients, and those brought into the WIS from the Atlantic Ocean by way of the Celtic Sea or the North Channel (Simpson and Rippeth, 1998; Hydes et al., 2004).

Freshwater discharges into the Irish Sea are rich in nutrients. Nitrogen and phosphorus enrichment is demonstrably anthropogenic (Nedwell et al., 2002) but silica enrichment is considered to be a natural result of the weathering of silicarich sedimentary rocks. Consequent on this enrichment, mixing 

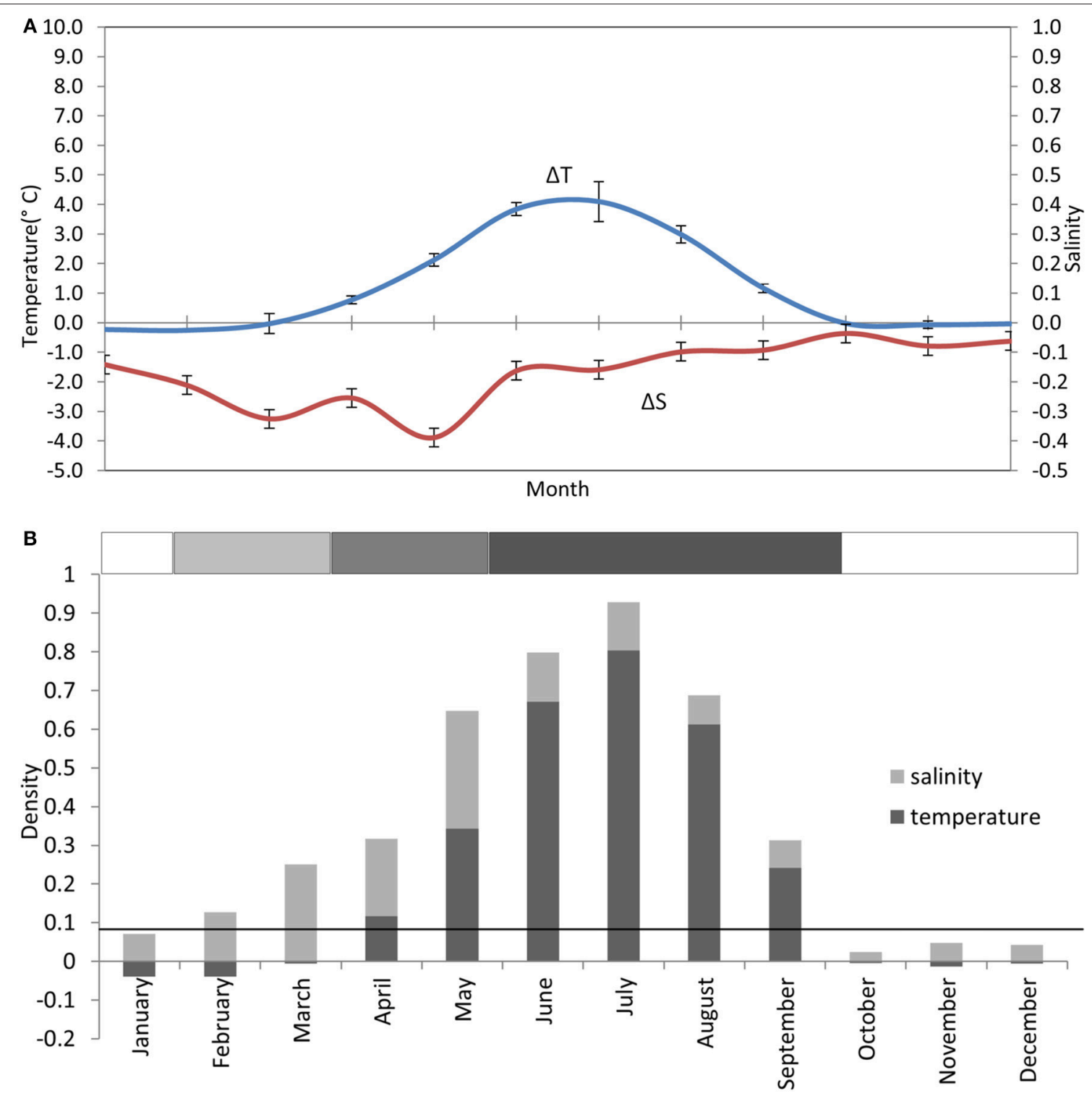

FIGURE 3 | Stratification climatology taken from monthly CTD profiles at the AFBI mooring site 38A in the WIS over a 10 year period (2005-2014). (A) Near-surface to near-seabed differences in temperature $\left({ }^{\circ} \mathrm{C}\right)( \pm \mathrm{StDev})$ and salinity $( \pm$ StDev), scaled to show their contribution to density layering. (B) Contributions of the temperature and salinity differences to the density layering in each month. The solid horizontal black line indicates where the near-bed density exceeds the near-surface density by $0.086 \mathrm{kgm}^{-3}$. The horizontal bar on top of (B) is the stratification bar, where white, no stratification; light gray, haline stratification; medium gray, haline+thermal stratification; and dark gray, thermal stratification.

calculations based on salinities (Table 5) imply that WIS water should be enriched compared to oceanic waters, but this is only evident for dissolved silica (Gowen and Stewart, 2005). The mixing calculation is not reliable for phosphate, which is influenced by estuarine processes (Zwolsman, 1994). It has been shown that $\mathrm{N}$ is lost from the oceanic source water (presumably as a result of denitrification) before it reaches the WIS, a journey that takes at least a year (Hydes et al., 2004; Moschonas et al., 2016).

Consequently, winter ToxN and DIP concentrations in the WIS are, despite some anthropogenic enrichment via river water, (a) similar to oceanic concentration at the shelf break and (b) below the OSPAR thresholds for enrichment. With the exception of some low salinity waters, $\mathrm{N}$ limitation is the expected norm in most temperate shelf seas and coastal waters (Ryther and Dunstan, 1971; Beardall et al., 1978; Tett and Droop, 1988; Gibson et al., 1997; Gowen et al., 2012). Winter N:P ratios are somewhat less than Redfield (Table 5) implying a predisposition to nitrogen limitation, and this is confirmed by DIP in summer, which is not fully depleted.

Silica-enriched freshwater augments Si concentrations in the WIS, so that the N:Si atomic ratio approaches 1 in winter (Gowen 


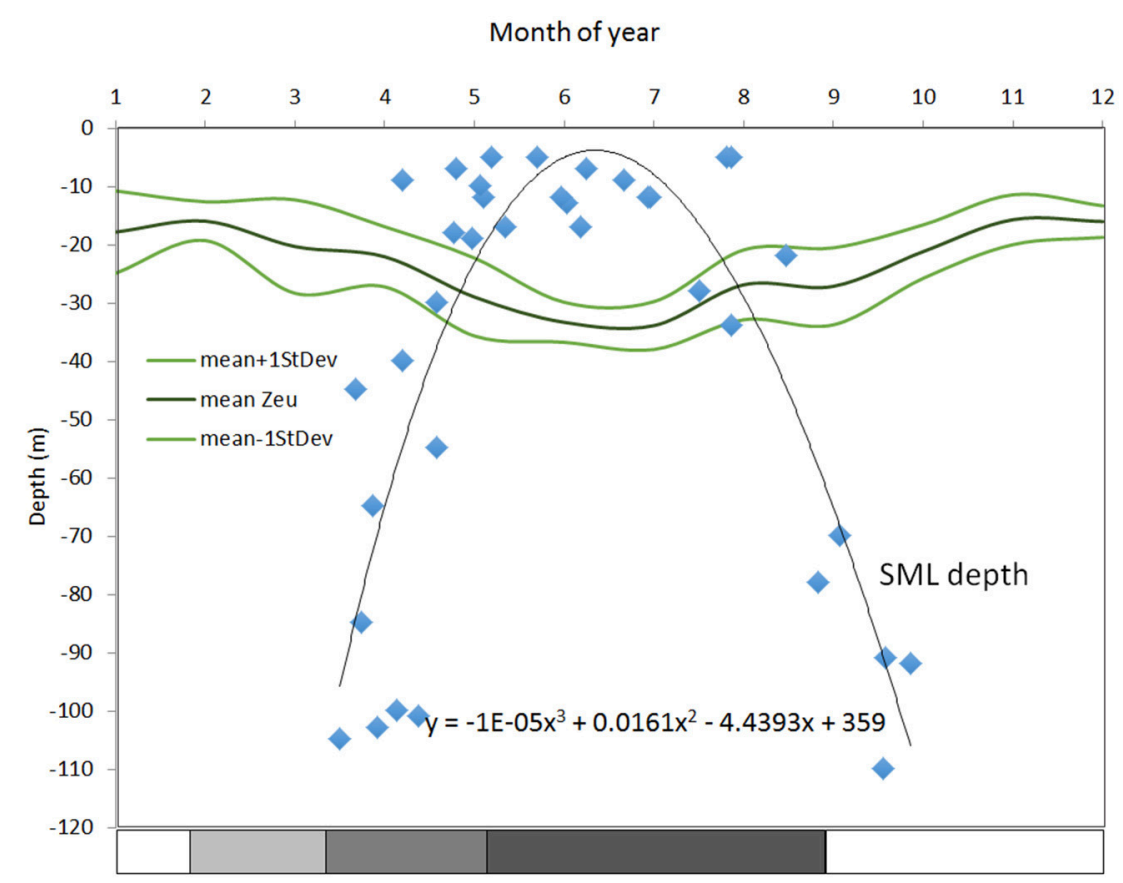

FIGURE 4 | Climatologies for the euphotic zone and thermal-surface mixed layer (th-SML) for the WIS in m. Surface mixed layer depth (m) from Gowen et al. (1995), defined as the depth at which temperature was $0.5^{\circ} \mathrm{C}$ less than that at $2 \mathrm{~m}$ over-plotted with the euphotic zone depth (Zeu) (defined as that of $1 \%$ surface PAR) calculated from $k_{D}$ for 2002-2012 from remote sensing (see Capuzzo et al., 2013 and references therein). The stratification bar indicates the salinity and temperature contribution to the overall density.

et al., 2002) and falls to about 0.4 in summer. Using uptake ratios, Gowen et al. (2000) showed that N ran out before Si in Irish coastal waters. In the WIS there appears to be adequate silica for diatoms and silicoflagellates for most of the year but during summer, the concentration in surficial waters is less than the halfsaturation concentration of $2 \mu \mathrm{M}$ (Escaravage and Prins, 2002) for silica uptake.

Finally, although there are no adequate time-series of oxygen concentration in the deep water of the WIS, there is evidence (Slinn, 1974; Gowen et al., 2008) that a small oxygen deficit (maximum 20\% below saturation) builds in the deep water during stratification, as it does in the northern North Sea (Lee et al., 2002; Queste et al., 2013). Such deep-water deoxygenation is part of the natural functioning of pelagic ecosystems in stratified waters. There is no evidence that the benthic community of the WIS is negatively affected by it. The burrowing decapod Nephrops norvegicus, an important member of the macrobenthos, is sensitive to hypoxia (Diaz and Rosenberg, 1995), and DARD photographic surveys continue to show good populations of the species in the seabed of the WIS (Gibson, 2011).

\section{Plankton Vigor}

The expectation for vigor emerges from the conceptual model (Figure 1) of the pelagic ecosystem as an open system driven by fluxes of energy and nutrients. The WIS was characterized above, as a seasonally-stratifying ecohydrodynamic regime in which nutrients accumulate during the autumn and winter.
In such regimes, the next phase in the seasonal cycle follows vernal increases in illumination and stratification, which allow phytoplanktonic photosynthesis to exceed respiration (Marshall and Orr, 1927; Sverdrup, 1953; Smetacek and Passow, 1990; Tett, 1990). It is useful to view the outcome as the yield (Gowen et al., 1992) of phytoplankton biomass from the accumulated limiting nutrient, nitrogen. Thus, the expected consequence of stratification is a pulse of increased chlorophyll-the Spring Bloom-with associated new production which is transferred to the benthos by sinking or to the heterotrophic plankton. Thereafter, the pelagic system is expected to tend toward local equilibrium: the condition in which available nutrients are mainly those locally regenerated and little production is available for export (Dugdale and Goering, 1967), except perhaps from a sub-surface chlorophyll maximum supported by new nitrogen. The latter is the case in the central North Sea (Fernand et al., 2013). Finally, a deepening SML, entraining deep-water nutrients, might be expected to generate an Autumn Bloom.

Observations correspond well to this expectation. Chlorophyll concentrations and microplankton biomass in the surface mixed layer show a spring peak (in May) and a lesser peak in AugustSeptember (Figure 6). There is some inter-annual variability in the timing of these blooms, but in the climatology made by fitting a TFS to column chlorophyll, the spring peak was reached c. day 150 (end of May) and the autumn peak c. day 230 (late August; Figure 8). A deep chlorophyll maximum is observed in late June (Gowen and Stewart, 2005; Rippeth et al., 

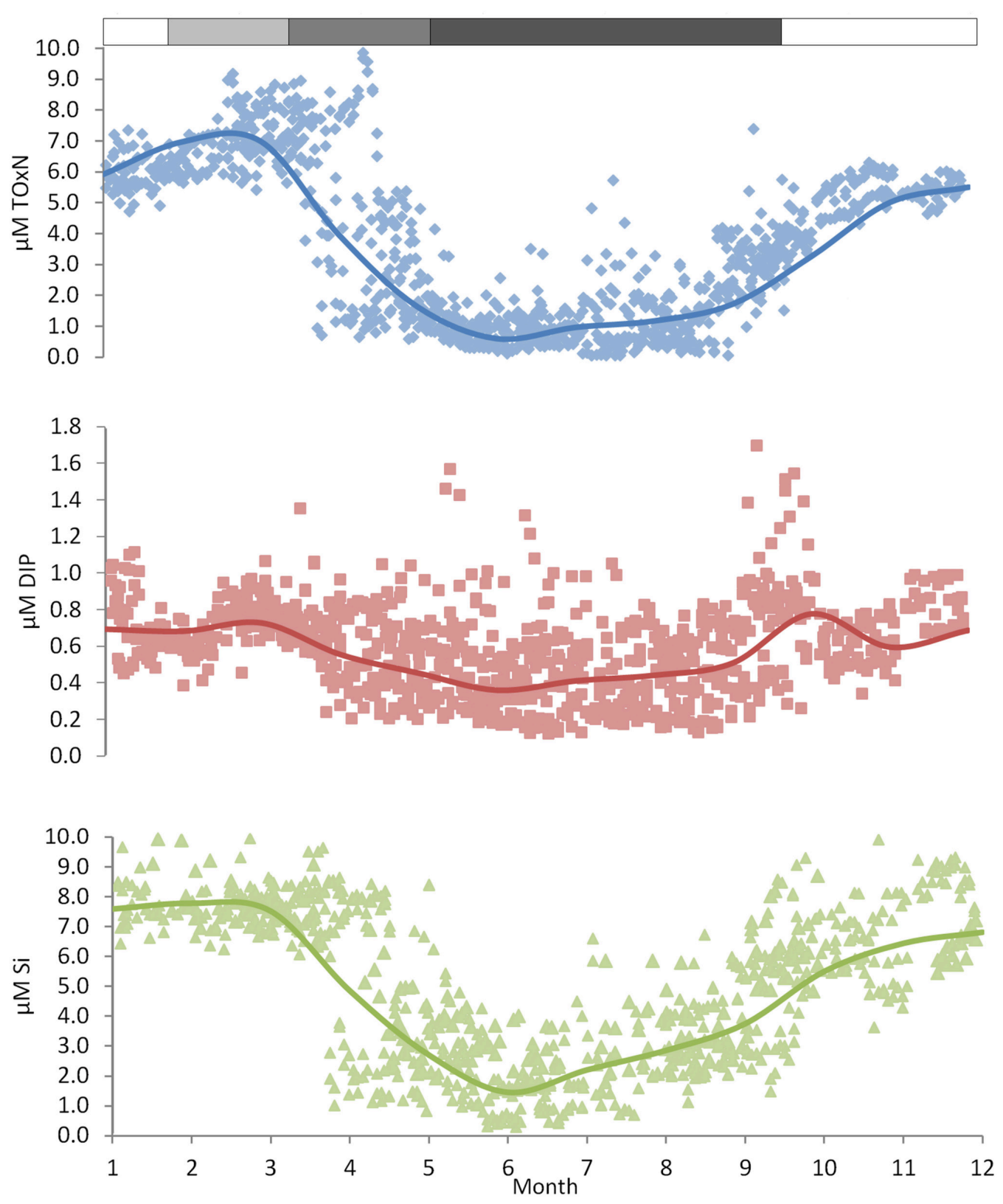

FIGURE 5 | Nutrient climatologies for the near surface seasonal inorganic nutrient cycle in $\mu \mathrm{M}$ (ToxN, total oxidized Nitrogen; DIP, dissolved inorganic phosphorous; Si, dissolved silicate) for the period between 2010 and 2014 at station 38A in WIS (methods in Gowen et al., 1995) with the solid line displaying the mean value; the horizontal bar indicates the salinity and temperature contribution to the overall density.

2014) and mid-July (Williams et al., 2013) as a frequent feature with concentrations of up to $8.1 \mathrm{mg} \mathrm{m}^{-3}$ (Gowen and Stewart, 2005).

The productive season is short. If defined as the period when chlorophyll exceeds $1 \mathrm{mg} \mathrm{m}^{-3}$ its climatological duration is from day 120 (1 May) until day 256 (13 September). Near-surface chlorophyll sometimes exceeded $10 \mathrm{mg} \mathrm{m}^{-3}$ during the Spring Bloom, fell to about $1 \mathrm{mg} \mathrm{m}^{-3}$ for a short period around day 180 (end of June) when nutrient concentrations are lowest, and rose to, at most, $4 \mathrm{mg} \mathrm{m}^{-3}$, during the peak in late summer/early autumn.

The deviations from the climatological envelopes in 1999 and 2000 do not seem part of any long term pattern: timeseries analysis has failed to show any temporal trend in DARD data from 1992 to 2004 (Gowen et al., 2008). Furthermore, concentrations of chlorophyll during the period after the Spring Bloom match those of $1-4 \mathrm{mg} \mathrm{m}^{-3}$ reported for 1968 by Slinn (1974), and for 1980-1982 by Richardson et al. (1985). However, 


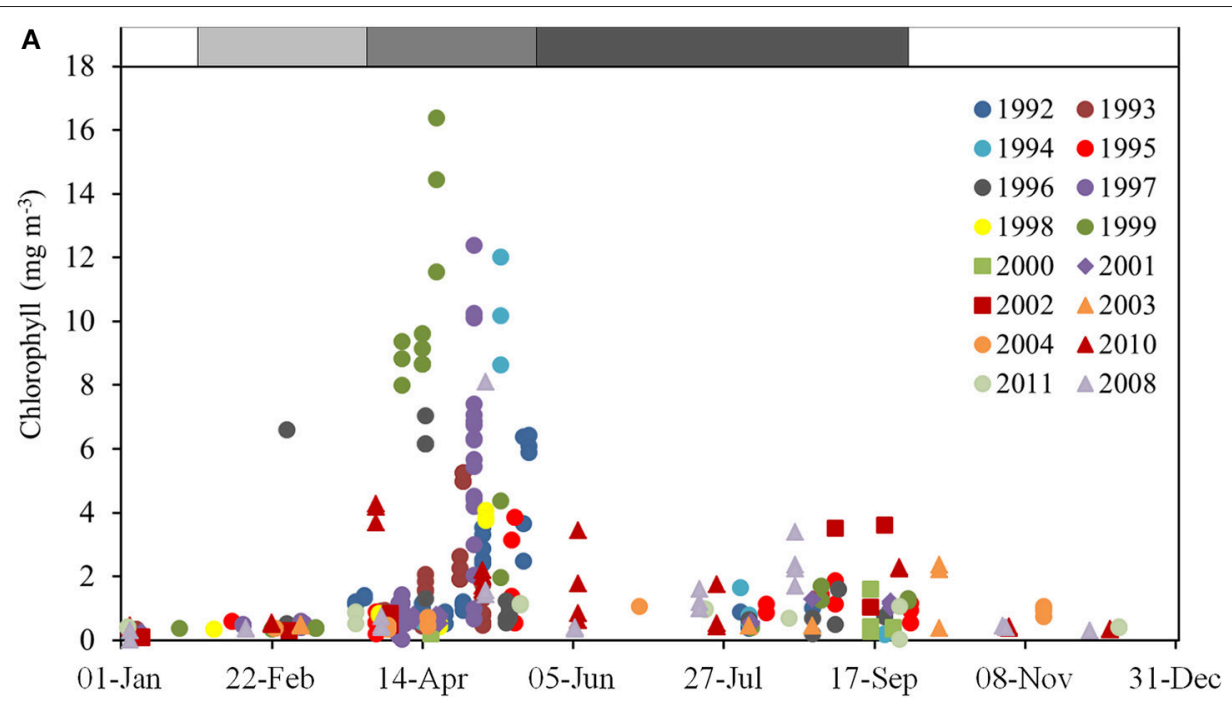

B
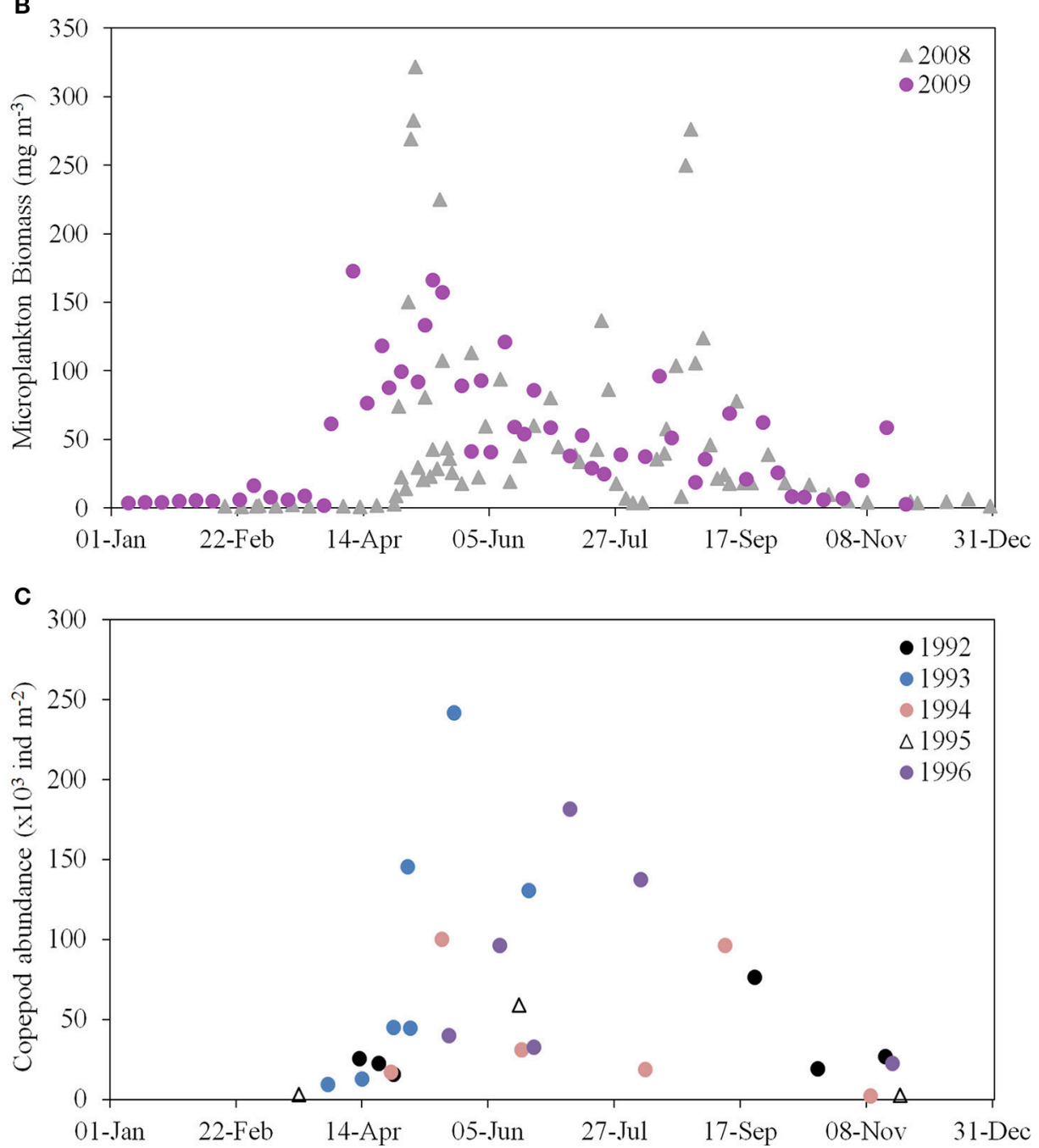

FIGURE 6 | Chlorophyll, microplankton and zooplankton climatologies for the WIS. (A) Chlorophyll concentration ( $\mathrm{mg} \mathrm{m}^{-3}$ ) in ship-sampled water at station 38A, 1992-2011 (AFBI, unpublished); (B) Microplankton (micro-algal and protozoan) biomass ( $\mathrm{mg} \mathrm{m}^{-3}$ ) at station 38A in 2008-2009 (Scherer, 2012); (C) Column copepod abundance (1000 individuals per $\mathrm{m}^{-3}$ ) estimated by vertical tow-net hauls in 1992-1996 (Gowen et al., 1997). 
Allen et al. (1998) have related increased phytoplankton biomass to an increasing trend of anthropogenic nutrients based on a long-term dataset west off the IoM.

Based on data from 1992 to 1993, Gowen and Bloomfield (1996) estimated gross seasonal production to be $140 \mathrm{~g} \mathrm{C} \mathrm{m}^{-2}$. Reworking these data and including observations from 1997 and 2010-11, led Scherer and Gowen (2013) to conclude that: the production season can last up to 5 months; gross seasonal production is in the range $101-140 \mathrm{~g} \mathrm{C} \mathrm{m}^{-2}$ and annual gross production is in the range from 157 to $291 \mathrm{~g} \mathrm{C} \mathrm{m}^{-2}$, with a central value of $204 \mathrm{~g} \mathrm{C} \mathrm{m}^{-2}$. These values derive from the fitted climatological TFS in Figure $\mathbf{7 B}$, and the range estimates include short-term as well as inter-annual variation; they do not imply that annual production varied between the limits given. The summer deep chlorophyll maximum contributes only a few grams of new production to these totals (Rippeth et al., 2009; Williams et al., 2013).

There is a difference between the season of chlorophyll $>1 \mathrm{mg}$ $\mathrm{m}^{-3}$ and phytoplankton growth. As evidenced by euphotic zone chlorophyll in Figure 7A, the micro-algal population typically begins to increase in early February, soon after day 30, and it begins its autumnal decrease at $\sim$ day 220 (July). It may be that salinity layering allowed some algae to remain in the euphotic zone in late winter, thus encouraging growth. Gowen et al. (1995) concluded that in 1992 a mean th-SML irradiance of between 6 and 10\% of daily mean surface PAR

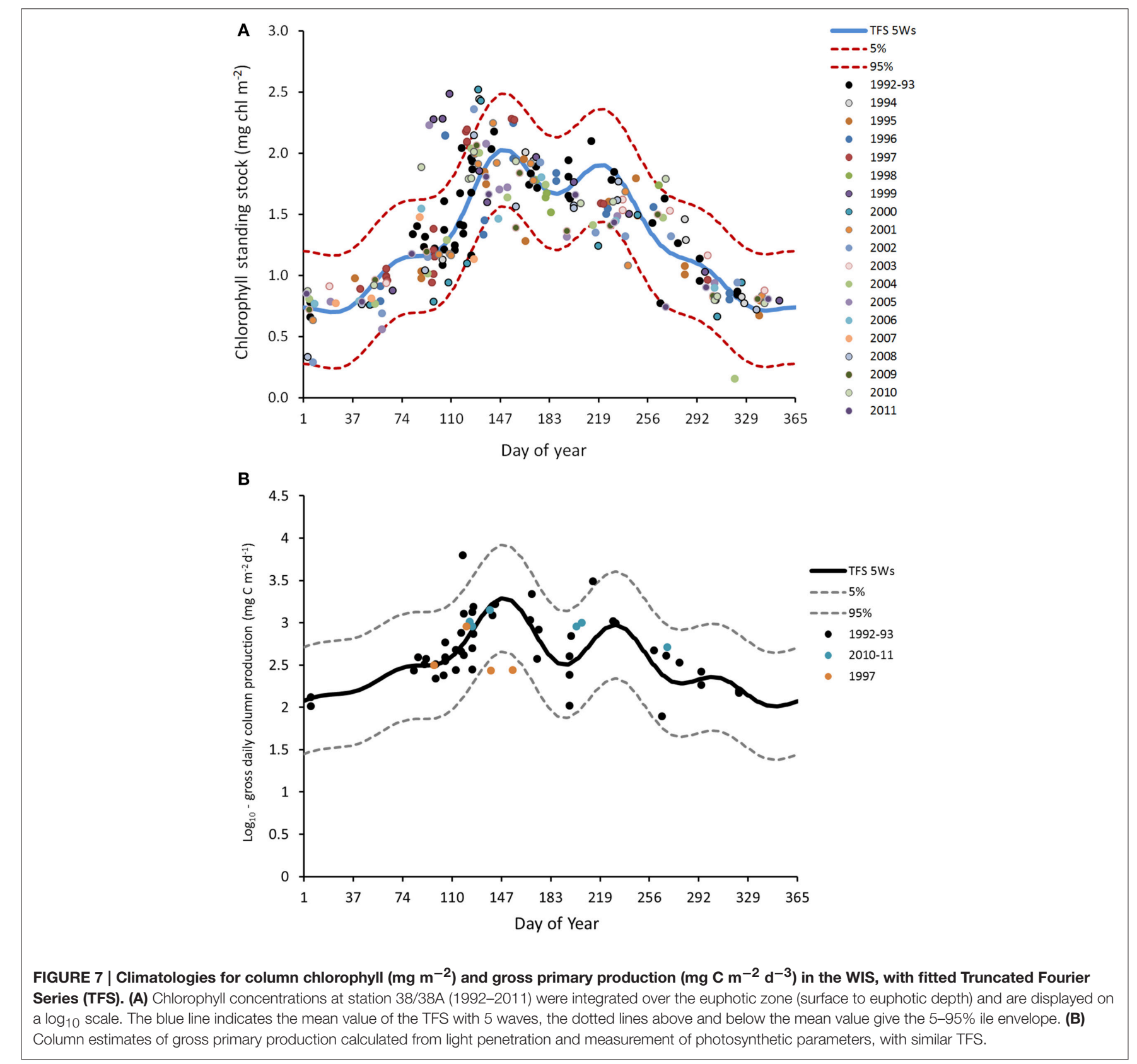


was required to trigger an obvious increase in chlorophyll in mid April. At this time the (thermal) mixed layer was still more than $80 \mathrm{~m}$ deep but shallowed rapidly, to $20 \mathrm{~m}$ in early May. We hypothesize that, as this happens and the Spring Bloom proceeds, population dynamics become more complex: cellular photosynthesis not only needs to exceed respiration, it must also exceed losses due to sinking and grazing, if population growth is to continue. So far as system vigor is concerned, it is, of course, the extra losses that are important, because these are the transfers to higher trophic levels. Gowen et al. (1999) showed transfer to copepods increased during the Bloom in 1997.

Observations allowing calculation of all the terms in the spring budget were made using data collected between 1992 and 2001 (Table 6). Because the terms were independently arrived at, the budget is not constrained to balance. This results in discrepancies: for example, calculated new production exceeds calculated net production. So does the total of losses to grazing and sinking, even if that total is less than calculated new production. One reason could be an over-estimation of respiration. But this is not the place to try to resolve such difficulties; we simply conclude that of the year's major pulse of net production, approximately half sinks, and half is consumed mainly by copepods but with some going to protozoans. Figure 7 suggests a second pulse of production in the late summer, driven by entrainment of deeper water. Less is known about the dynamics of this bloom. In 2008-2009 there were more grazing protozoans at this time. Although copepod numbers typically decreased after the Spring Bloom (Figure 6C) grazing pressure may remain high at this time, because of warmer temperatures and larger individuals.
The sedimentation flux in Table 7 was calculated on the assumption that it should balance the increase in sea-bed oxygen demand (SOD) observed during the Spring Bloom period in 1998 (Trimmer et al., 1999). In 2005, Hill (2007) observed a peak in deep-water chlorophyll within a few weeks of the Spring Bloom in the upper waters confirming that at least part of the transfer is the sinking of living phytoplankters. Using a relationship between water depth and organic flux (Suess and Müller, 1980; Trimmer et al., 1999) estimated the annual input of new production to the benthos as $17.2 \mathrm{~g} \mathrm{C} \mathrm{m}^{-2}$, less than some of the Spring Bloom estimates. Studies later in the year, to estimate sedimentation from the Autumn Bloom, are lacking. Nevertheless, it is possible to make rough estimates (Table 7) of the annual flux of organic carbon from phytoplankton through to zooplankton as well as benthos, and then on to fish.

Although, high phytoplankton biomass $\left(16-23 \mathrm{mg} \mathrm{chl} \mathrm{m}{ }^{-3}\right.$, Gowen and Bloomfield, 1996) and high cell counts in total (1.6 $\times$ $10^{6}$ diatom cells $\mathrm{L}^{-1}$, Scherer, 2012) have been observed during the peak of the Spring Bloom, average chlorophyll concentration for the period between March and September never exceeded the 90th percentile of the OSPAR eutrophication threshold of $10 \mathrm{mg}$ $\mathrm{m}^{-3}$ for coastal offshore waters (Gowen et al., 2008) and the average cell abundance never exceeded the OSPAR thresholds for any single taxon of $10^{6}$ or $10^{7}$ cells $\mathrm{L}^{-1}$ in total (McKinney et al., 1997; Gowen et al., 2008). The Spring Bloom is rapidly followed by an increase in numbers of planktonic copepods (Figure 6C), the dominant zooplankter in the WIS (Scrope-Howe and Jones, 1985), implying an effective transfer of production from phytoplankton to their mesozooplankton consumers. Gowen et al. (1999) estimated that $22 \%$ of Spring Bloom production was consumed by copepods in 1997. Additional primary production

TABLE 6 | Primary production at AFBI's mooring station (38/38A) during the Spring Bloom based on Gowen et al. (1998a) for 1992-1996 and unpublished AFBI data.

\begin{tabular}{|c|c|c|c|c|c|}
\hline Variable & 1992-1996 & 1997 & 1998 & 2001 & Method \\
\hline Duration of bloom, days & 61 & 59 & 81 & 92 & Between winter maximum and summer minimum in DIN \\
\hline DIN drawdown, mmol m $\mathrm{m}^{-2}$ & & 429 & 675 & 700 & Observed change in total column DIN \\
\hline \multicolumn{5}{|c|}{ Production or transfer, $\mathrm{g} \mathrm{C} \mathrm{m}^{-2}$} & $\begin{array}{l}\text { Except for new production, calculated for each visit; interpolated to daily values, } \\
\text { and summed }\end{array}$ \\
\hline Gross & 52 & 40 & 53 & 76 & $\begin{array}{l}{ }^{14} \text { C-measured photosynthetic parameters, column production calculated from submarine } \\
\text { light profile; interpolated from chlorophyll when parameters unavailable (Gowen and } \\
\text { Bloomfield, 1996) }\end{array}$ \\
\hline Net (phyto-plankton) & & 20 & 34 & 44 & $\begin{array}{l}\text { Gross production }(P) \text { less phytoplankton respiration (R) estimated from } R=a . X+b . P \text {, } \\
\text { where } a=1.5 \mathrm{mg} \mathrm{C} \mathrm{(mg} \mathrm{chl)})^{-1} \mathrm{~d}^{-1} X=\text { chl conc. and } b=0.5 \text { (Tett, 1990; Lee et al., 2003) }\end{array}$ \\
\hline New & & 34 & 54 & 56 & DIN drawdown $\times$ Redfield $\left[80 \mathrm{mg} \mathrm{C}(\mathrm{mmol} \mathrm{N})^{-1}\right.$ ] \\
\hline Transfer to copepods & 19 & 8 & 6 & 19 & $\begin{array}{l}\text { Ingestion rates } \times \text { copepod numbers (Gowen et al., 1999) in three size categories: small, } \\
6.3 \text {; medium, 41; large, } 279 \mathrm{ng} \mathrm{chl} \mathrm{ind}{ }^{-1} \mathrm{~d}^{-1} \text {; and } 30 \mathrm{mg} \mathrm{C} \mathrm{mg} \mathrm{chl}^{-1}\end{array}$ \\
\hline Transfer to protozoans & & 5 & 0.2 & 3 & $\begin{array}{l}\text { Modeled, temperature and algal biomass dependent, clearance rates of ciliates (506) and } \\
\text { heterotrophic dinoflagellates }\left(740 \text { pg C cell }{ }^{-1}\right) \text {, with maximum clearance at } 20^{\circ} \mathrm{C} \text { of } 1.7 \mathrm{~L} \\
\text { (mg protozoan } \mathrm{C})^{-1} \mathrm{~d}^{-1} \text { (Lee et al., 2003) }\end{array}$ \\
\hline Transfer to benthos (sinking) & & 15 & 20 & 29 & $\begin{array}{l}\text { Carbon flux required to satisfy sediment oxygen demand and flux-depth relationship } \\
\text { (Trimmer et al., 1999) }\end{array}$ \\
\hline Sum of transfers & & 28 & 26 & 51 & \\
\hline
\end{tabular}


TABLE 7 | Estimates of annual production $\left(\mathrm{g} \mathrm{C} \mathrm{m}^{-2} \mathrm{a}^{-1}\right)$ in the WIS and ICES VIIA at several trophic levels.

\begin{tabular}{|c|c|c|c|c|c|}
\hline & \multicolumn{2}{|c|}{ ICES VIIA (Irish Sea) } & \multicolumn{2}{|c|}{ WIS } & \\
\hline & $1973-1978$ & 2002 & 1978-1982 & 1992-2011 & \\
\hline Area (in 000 km²) & 48 & 48 & 3.5 & 3.5 & VIIA: (Brander and Dickson, 1984); WIS: this paper \\
\hline Gross photo-synthetic primary production (GPP) & & & & 204 & (Scherer and Gowen, 2013) and this paper \\
\hline Net primary production (NPP) & & & & 104 & Subtracting 49\% GPP for algal respiration \\
\hline New production & & & & 63 & $\begin{array}{l}\text { From Spring nutrient drawdown (Table 5), plus one third for } \\
\text { Autumn including c. } 5 \mathrm{~g} \mathrm{C} \mathrm{m}^{-2} \text { for DCM over } 60 \text { days } \\
\text { (Rippeth et al., 2009; Williams et al., 2013) }\end{array}$ \\
\hline Transfer to copepods & & & & 22 & Spring estimates (Table 5), × 2 \\
\hline ... To protozoa & & & & 8 & Spring estimate, $\times 3$ \\
\hline Sedimentation & & & & 40 & $\begin{array}{l}\text { Water depth relationship (Suess and Müller, 1980) used to } \\
\text { calculate annual carbon flux for } 93 \text { m (Trimmer et al., 1999: } \\
38 \% \text { of NPP) }\end{array}$ \\
\hline Pelagic secondary production & & & & 3.0 & Ten percent of transfer to copepods + protozoa \\
\hline Benthic secondary production & & & & 4.0 & Ten percent of sedimentation \\
\hline Nephrops landings & & & 0.25 & 0.29 & $\begin{array}{l}\text { (Brander and Bennett, 1986; Lynam et al., 2011) taking } 1 \mathrm{~kg} \\
\text { wet weight }=100 \mathrm{~g} \mathrm{C} \text {, ascribed only to WIS }\end{array}$ \\
\hline Demersal fisheries catch & 0.08 & 0.03 & & & $\begin{array}{l}\text { (Brander and Dickson, 1984; Vincent et al., 2004), taking } 1 \mathrm{~kg} \\
\text { wet wt }=100 \mathrm{~g} \mathrm{C}\end{array}$ \\
\hline Pelagic fisheries catch & 0.09 & 0.01 & & & Ditto \\
\hline
\end{tabular}

Fisheries catch ascribed to whole area of ICES VIla, whereas Nephrops assumed to be taken solely from the deep mud sea-bed of the WIS.

likely passes to ciliate and dinoflagellates consumers, supporting the increases shown in Figure 8. There is effective transfer of biomass from near surface to deep waters and the benthos as evidenced by increased sediment oxygen demand (Trimmer et al., 1999; Hill, 2007). The Trimmer et al. (1999) study suggested that this benthic demand required $46 \%$ of total spring phytoplankton production or $61 \%$ of new production. Based on Trimmer's $17.2 \mathrm{~g} \mathrm{C} \mathrm{m}^{-2}$ new production, Scherer and Gowen (2013) estimated that, $4.4 \mathrm{~kg} \mathrm{C} \mathrm{ha}^{-1} \mathrm{y}^{-1}$ was available to animals at trophic level 3 in the benthos. A Nephrops catch of $1.4 \mathrm{~kg} \mathrm{C}$ $\mathrm{ha}^{-1} \mathrm{y}^{-1}$ (Gibson, 2011) therefore represents $31 \%$ of the available phytoplankton carbon.

Thus, the WIS appears to be a well-functioning pelagic ecosystem that well exploits available resources (the nutrients available at the end of winter) during the Spring Bloom and efficiently transfers Bloom primary production to higher trophic levels. The sub-surface chlorophyll maximum may be an additional source of new production in summer, as may be the late Summer Bloom that occurs in some years.

\section{Plankton Organization}

The argument in previous subsections has been straightforward, because expectations for vigor (nutrients and production) arise deterministically from ecohydrodynamics. This is less clearly the case in respect of organization. The pelagic food web is complex and may have several stable conditions that equate with GES. Links between these conditions and ecohydrodynamics are less obvious, and have been more disputed than those for vigor. There may therefore be a range of expectations for the functional biodiversity and the trophic links in a healthy, fully-functioning, pelagic ecosystem of a seasonally-stratified regime. Furthermore, there is no consensus on the identification of functional groups in the plankton; Table 4 lists those that we have considered for the UK monitoring programme. Finally, also to be taken into account in assessing whether organization is adequate for GES is the extent of functional response diversity (redundancy; Folke et al., 2004; Hughes et al., 2005) within functional groups. We view zooplankton feeding traits (Kiørboe, 2011) as part of functional response diversity insofar as they determine how $\mathrm{X}$ catches $\mathrm{Y}$, and as relevant for organization only if they determine whether $\mathrm{X}$ catches $\mathrm{Y}_{1}$ instead of $\mathrm{Y}_{2}$.

\section{A Variety of Expectations for the Pelagic Food Web}

The Spring Bloom, as an event associated with the stabilization of turbulent conditions while nitrate and silicate are plentiful, is expected to be dominated by pelagic diatoms (Margalef, 1978; Parsons, 1979; Smayda, 1980; Cushing, 1989), which in turn provide food for copepods and fish in what is thought of as the classical pelagic food web. According to Margalef $(1967,1978)$ the subsequent seasonal evolution of the pelagic system is less energetic. Stratified and nutrientdepleted summer conditions, should give rise to a shift from smaller (e.g., Skeletonema) to larger (e.g., Thalassiosira) chainforming diatoms, and then to large cylindrical diatoms (e.g., Rhizolenia) and large dinoflagellates (e.g., Protoperidinium), with the final stage dominated by large dinoflagellates and small photoautotrophic flagellates.

The increasing size of primary producer should be accompanied by a shift from small to large copepods. Williams et al. (1994) concluded that the simpler web dominated by larger copepods (especially Calanus spp.) feeding on diatoms, was associated with thermally stratified waters of N-W European shelf seas, whereas a complex food web in which small copepods 


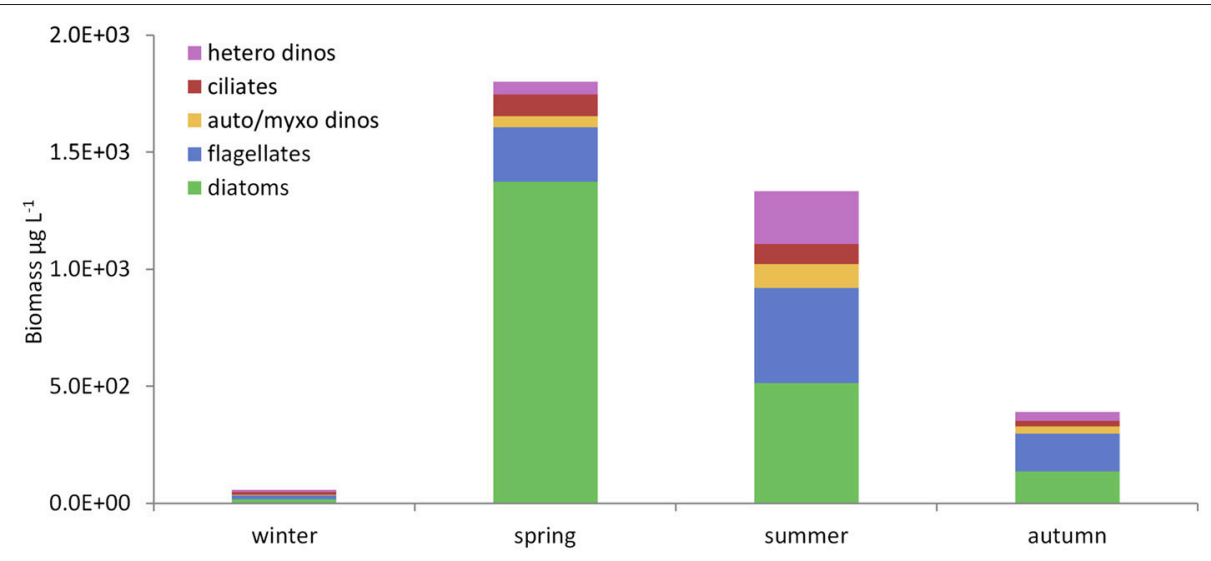

FIGURE 8 | Seasonal changes in microplankton composition in the WIS in 2008-2009. Mean bio-volumes ( $\mu \mathrm{g} \mathrm{L}^{-1}$ ) of each functional microplankton group (Table 4) in the seasons defined in Table $\mathbf{8}$ (drawn from Scherer, 2012). Hetero dinos, heterotrophic dinoflagellates; ciliates, oligotrophic ciliates; auto/myxo dinos, photoautotrophic and myxotrophic dinoflagellates; flagellates, micro-flagellates (all nutritional modes); diatoms, centric and pennate diatoms.

and meroplankton were the grazers, was typical of inshore mixed waters (e.g., the southern North Sea, Tett et al., 1993; Halsband and Hirche, 2001; Wesche et al., 2007; see also: Boersma et al., 2015). These small crustaceans, including cyclopoid and harpacticoid as well as calanoid copepods, have a variety of strategies for population overwintering. It is because of the different consequences of small, short-lived, and larger, longer-lived, copepods for seasonal trophic relationships that we distinguish them in our categorization of planktonic lifeforms (Table 4).

Legendre and Rassoulzadegan (1995) were of the opinion that the variety of different systems was best seen as a continuum with the classical pelagic food web at one end and the "microbial loop" at the other. However, subsequent studies (e.g., Gismervik et al., 1996; Gismervik, 2005; Figueiredo et al., 2009) have demonstrated additional roles for pelagic protozoans and suggest that the Legendre model is insufficiently complex.

Stratified seas dominated by picophytoplanktonic production are generally thought to be characteristic of the oligotrophic ocean gyres (Raven, 1998; Morán et al., 2010). Thus, the expectation for the WIS is that of the herbivorous and multivorous webs, with the additional complexity at the protozoan level mentioned above.

The third main trophic group of zooplankters to consider is those loosely called "predators" because they feed on the "grazers" (e.g., chaetognaths and euphausiids). This group is a bridge to fish and other large animals, both as a source of food and also because some are planktonic as young and become nekton. While predator generation times are typically longer than those of the grazers, and thus may smooth fluctuations in the abundance of their prey, their populations nevertheless often display strong seasonality.

Despite the importance of all these predators in food webs, their biology is comparatively poorly understood (Mitra et al., 2014), although fish larvae are an exception to this. Expectations for seasonally stratified waters can, thus, only loosely be based in theory. In the case of the WIS we expect chaetognaths because of their ubiquity, diurnally vertically migrating euphausiids because of the existence of deep water, scyphozoans because of the proximity of shallower waters, and fish larvae. Finally, the balance between "jellies" (meaning scyphozoans, hydrozoans, and ctenophores) and other zooplanktonic predators may be important.

\section{Observations of Microplankton}

We label the community of autotrophic, myxotrophic and heterotrophic pelagic micro-organisms $<200 \mu \mathrm{m}$ microplankton, including prokaryotes but excluding metazoa (Dussart, 1965; Tett and Wilson, 2000). Little is known about prokaryotes in the WIS, with the exception of the summer in 1980 when bacterial biomass in the euphotic zone was a little greater than that of the phytoplankton (Fogg et al., 1985).

Figure 8 shows the seasonal pattern of abundance (as biovolume) of the main eukaryotic microplankton functional groups in 2008 and 2009. As expected, diatoms were the major component of the Spring Bloom. This was also the case in 1949 and 1950 (Williamson, 1952 using tow-nets and the Hardy plankton indicator), 1977 (Beardall et al., 1978), and in the mid-late 1990s and early 2000s (AFBI unpublished data; McKinney et al., 1997; Gowen et al., 2012). However, the Bloom was different in two out of the 12 years for which there are adequate data. In 1997 (Gowen et al., 1999) and 2001 (Gowen and Stewart, 2005), microflagellates ( $\leq 10 \mu \mathrm{m})$ together with the silicoflagellate Dictyocha speculum and microflagellates, respectively were numerically dominant.

As Figure 8 shows for 2008 and 2009, both the aggregate biovolume of diatoms, and their relative contribution to total microplankton biovolume, was maximal in spring, whereas the biovolume of microflagellates was greatest in summer and their contribution remained high in the autumn. Phytoflagellates and zooflagellates were not routinely distinguished, but both trophic types occurred. Oligotrich ciliates were found in all seasons, as were autotrophic and myxotrophic dinoflagellates; heterotrophic dinoflagellates were most abundant in summer. 
Each functional group comprised a variety of species (Scherer, 2012).

Gowen et al. (2012) found great variation in diatoms of the Spring Bloom in the WIS, which points to substantial redundancy within the diatom functional group.

\section{Observations of Mesozooplanktonic Grazers}

Copepods are the main grazer and numerically most abundant mesozooplankters in the WIS (Scott, 1907; Williamson, 1952; Scrope-Howe and Jones, 1985; Gowen et al., 1998a, 1999). Gowen et al. (1997) argued that the presence of egg-bearing females and nauplii demonstrated that populations of Calanus, mainly C. helgolandicus, were reproducing in the WIS. As it is unlikely that these species (especially C. finmarchicus, which requires cold water to enter a diapause state) over-winter in the WIS it is believed that the populations are renewed in spring from oceanic inflows. Calanus spp. were likely to have been the main grazers in 1980 (Scrope-Howe and Jones, 1985) and in a few other years (Nash and Geffen, 2004), but smaller copepods were more important during the Spring Bloom in 1998 (Gowen et al., 1999, taking about a quarter of gross primary production. They were numerically dominant in all years (Scrope-Howe and Jones, 1985; Gowen et al., 1998a). The most abundant species in spring were the calanoids Pseudocalanus, Temora, and Acartia. The cyclopoid Oithona reached a peak in July, and Acartia peaked in August. The four calanoid copepods mentioned all belong to the "nonpredator" copepod functional groups identified by Benedetti et al. (2015), and distinguished by feeding methods (Kiørboe, 2011). Other grazers identified by Scrope-Howe and Jones (1985) were appendicularians and meroplankton, but in 1980 and 81 these only made up $\sim 10 \%$ of total grazer abundance.

\section{Observations of Zooplanktonic Predators}

Other planktonic predators in the WIS include scyphozoans, chaetognaths, euphausiids, ctenophores, and fish larvae. Although, many of these organisms (e.g., euphausiids, Tarling et al., 2010) are not well-sampled by the small tow-nets used for copepods, data are available from two other sources. One is as a by-product of young fish surveys with larger and faster nets and also actual surveys conducted on jelly-fish in May and June each year from 1994 to 2009 , between 53.00 and $54.25^{\circ} \mathrm{N}, 4.75$ to about $6.25^{\circ} \mathrm{W}-$ a region that includes the main part of the WIS but also mixed waters close to the Irish coast. Chaetognaths were additionally collected with a high speed net (Dickey-Collas et al., 1996b) during surveys in 1994. The other source was the analysis of fish and invertebrate stomach contents.

Observations on larval and juvenile fish in 1994 (DickeyCollas et al., 1996a) showed that Irish coastal areas are spawning grounds, and provide food for the larvae due to an early start of the Spring Bloom. When the seasonally stratified region of the WIS establishes the young fish are entrained offshore where the later Spring Bloom and a copepod peak provides additional food.

The jelly-fish surveys showed a trend of increase in jellies from 1994 to 2009 (Lynam et al., 2011; Bastian et al., 2014).

The chaetognath population appears to reproduce during the summer in the WIS, and to overwinter there as non-reproducing young, even if most individuals belonged to the oceanic species
Sagitta elegans rather than the neritic S. setosa. Biomass and egg production were greater in the WIS than in other parts of the Irish Sea (Dickey-Collas et al., 1996b). An examination of chaetognath gut contents from the east of the Isle of Man, (shallow and weakly stratified) showed that the main prey was small copepods (Alvarez-Cadena, 1993).

Meganyctiphanes made up $15 \%$ of the stomach content of squids commercially landed at Irish Sea ports (Collins et al., 1994). It was also found in the stomachs of demersally-caught fish from the WIS in the second half of the year, forming the bulk of the food intake by small Trisopterus minutus (poor-cod) at this time (Armstrong, 1982).

\section{Conclusions about Organization}

In general, the plankton of the WIS appear to form a fully functioning system with good functional response diversity at producer, grazer, and predator levels. The usual dominance of the Spring Bloom by diatoms feeds copepods and ensures a food supply to the benthos; subsequently the food web shifts to the more resilient multivorous type. Observations of the stomach contents of squid and fish show that the pelagic web is well linked to higher trophic levels, the euphausiid Meganyctiphanes playing an important role in nourishing small nektonic predators. The main difference from expectation is that Calanus spp. are in most years less abundant than expected; it may be that the bottom water of the WIS in winter is neither sufficiently cold nor sufficiently well isolated to provide a refuge for the large copepods. This contrasts with the situation in the seasonally stratified northern North Sea (Lynam et al., 2011).

Table 8 gives a summary of the seasonal changes in the pelagic habitat of the WIS and indicates at what point in time these seasonal changes happen defining a "season."

\section{Consequential Aspects of Pelagic Food Web Functioning}

At issue is whether the "pelagic habitat" in the WIS provides good conditions for larger animals including fish and sea-feeding higher vertebrates, and for the young of benthos nekton. There is an interpretational difficulty, as much data concerning fisheries and sea-birds relate to larger scales. Fish stocks and fish landings are mainly reported from ICES fisheries area VIIa, which covers the Irish Sea between $52^{\circ} \mathrm{N}$ and $55^{\circ} \mathrm{N}$, a much larger area $(48,000$ $\mathrm{km}^{2}$, Brander and Dickson, 1984) than the $\sim 3000 \mathrm{~km}^{2}$ of WIS, and one that is heterogeneous in respect of ecohydrodynamics. However, an important part of the link between plankton and fish is by way of plankton-feeding fish larvae, and a good deal is known about their distribution and movements.

The western part of the Irish Sea is an important spawning and nursery ground for a variety of fish, many commercially exploited. Spawning begins in Irish coastal waters in early Spring, and young fish move (or are entrained) offshore into the stratified waters of the WIS in June, taking advantage of better food and feeding conditions there (Dickey-Collas et al., 1996a). Four decades ago these fish recruited to productive pelagic and demersal fisheries, the major landings (by weight) being of herring (pelagic) and cod and whiting (demersal) (Brander and Dickson, 1984; Lynam et al., 2011). At that time a smaller 


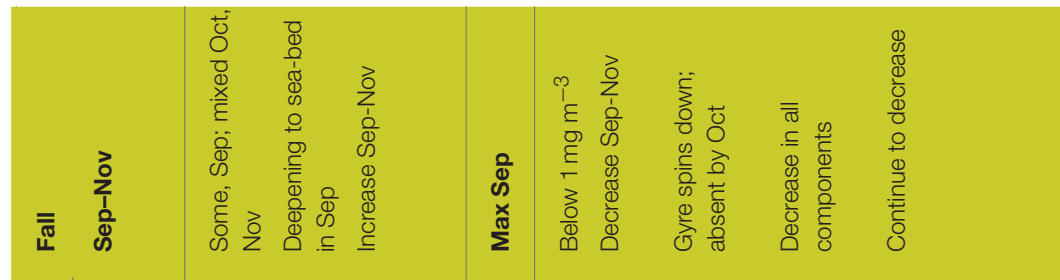

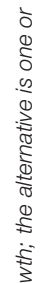
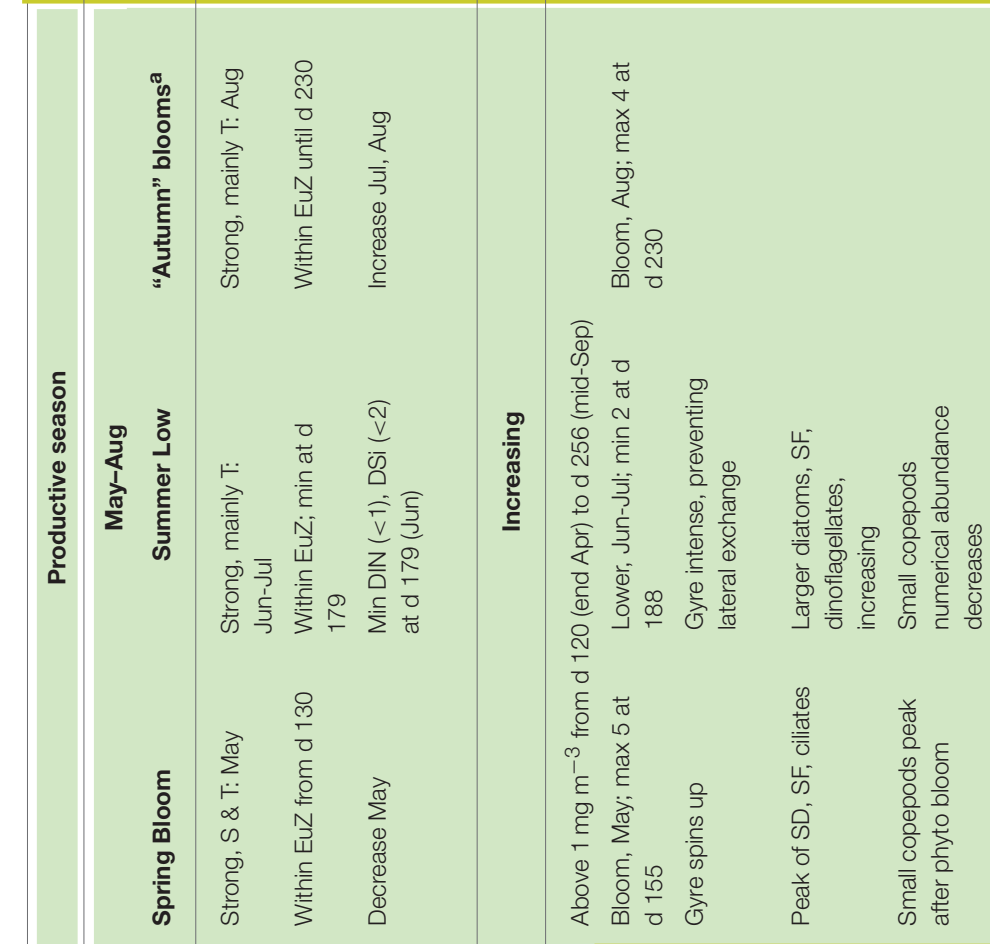

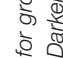

ลे हे

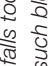

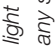

है
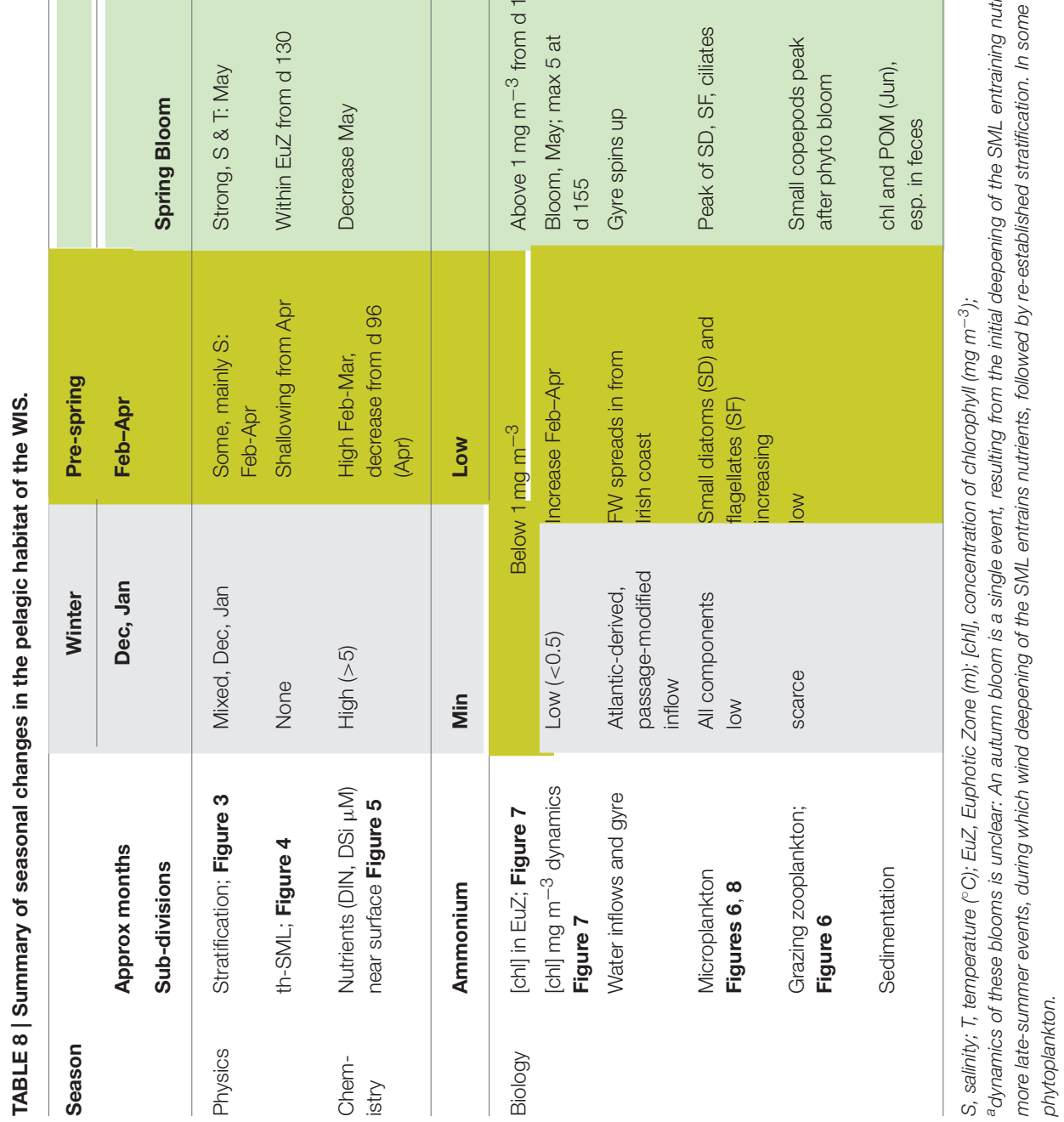
amount of the burrowing decapod, $N$. norvegicus was caught. $N$. norvegica adults inhabit burrows in the mud that covers much of the seabed beneath the WIS, where they are predated by cod (Armstrong, 1982; Brander and Bennett, 1986). It is thus perhaps unsurprising that a decline in the cod population (Kelly et al., 2006), due to overfishing, has resulted in an increase in the amount of $N$. norvegica landed: by 2002 the weight (and value) of shellfish landings from ICES sea-area VIIa (the Irish Sea as a whole) greatly exceeded the weight and value of finfish landings. Estimated Nephrops landing into Northern Irish ports in 2008 were $7876 \mathrm{t}$ with a market value of $£ 14.2$ million (Gibson, 2011).

The life cycle of Nephrops seems to adapt them to the WIS gyre, which retains their pelagic larvae (White et al., 1988). Settling to the deep mud sea-bed within this gyre, the larvae grow into burrowing adults that exploit sedimenting organic matter. So, although this part of the WIS ecosystem is not in a pristine state, it is nevertheless functioning well in supporting higher trophic levels and in delivering ecosystem services (such as the Nephrops fishery) to human society. The shift from cod to Nephrops might be seen as evidence of the system's adaptive capacity, or resilience in the face of fishing pressure. Furthermore, it makes more efficient use of primary production, prawns occupying a trophic level below that of cod.

Most sea-birds feeding in the WIS have flown there from distant nesting sites, but there are ample data from shipboard observers concerning distributions (MacKey and Giménez, 2004). The feeding preferences of birds can be identify as plankton feeders and those that take larger fish or fisheries discards. The seabirds observed in large numbers over the WIS during the "breeding" and "post-breeding" seasons include the Manx shearwater (Puffinus puffinus), which feeds near the seasurface on small planktonivorous pelagic fish (Carboneras et al., 2016). Their population is monitored only on the island of Skomer in St George's Channel, showing no discernible longterm trend in chick rearing success or adult survival rates since 1986 (JNCC, 2015). Guillemots (Uria aalge), razorbills (Alca torda), and gannets (Morus bassanus), birds that dive for small shoaling planktonivorous fish and larger plankton, are also common in the WIS. Although, the exact diet of such birds has not been studied in the WIS, the fish on which they prey are likely to include sand eels and young, i.e., small, gadoids, and clupeiods. Existing relevant population data (JNCC, 2015) suggest that birds are breeding successfully, implying good feeding. However, according to ICES Ecosystem Overviews (published in March 2016) trends in the abundance of many breading seabirds are on a broad downwards trend in the Celtic Seas region since the early 2000s, while species that breed elsewhere have been reported to feed in the area (ICES Ecosystem overview, 2016).

\section{Counter Arguments}

In this subsection are considered arguments against the claim that the WIS is in GES. Significant counter-arguments must show that the WIS is less than the fully-functioning pelagic ecosystem expected under the identified ecohydrodynamic conditions. Evidence of change is relevant only if the change is adverse to full-functioning and the provision of ecosystem services.

\section{Physical and Chemical Conditions}

The WIS is not completely isolated from human-impacted waters on the Irish and British coasts. Riverine nutrients transferred through these waters add to winter concentrations in the WIS and, in the case of nitrogen, compensates for de-nitrification. However, even if the vigor of the WIS pelagic system is somewhat increased over pristine levels, it does not appear to have resulted in any undesirable disturbance to the system's organization. The natural enrichment with silica may be helping in this, by ensuring that-at least during the Spring Bloom-most nutrient-N is converted into diatoms.

The waters of the WIS are unusually turbid for a stratified shelf sea. This seems to be due to the suspended sediment loads in the adjacent tidally stirred waters, which make up most of the Irish Sea. It is possible that these loads are higher than they would be under pristine conditions, due to tidal stirring and perhaps to trawling damage to the sea-bed (Service and Magorrian, 1997). Were there greater transparency, the WIS Spring Bloom might commence earlier, the presently short productive season might lengthen, and the seasonal succession of phytoplankton might proceed to the stage of ceratioid dominance (Margalef, 1978) that is missing here but found in the adjacent Firth of Clyde (Tett, 1969), where seasonal stratification persists longer into autumn.

\section{Production and Fisheries}

Brander and Dickson (1984) demonstrated that fish production, per unit area, was lower in the Irish Sea than in the North Sea. They thought that this was "principally due to lower recruitment [of young fish to the fishery in the Irish Sea], which may in turn be due to the short, late production cycle in that area." However, their evidence for the production cycle was derived from CPR color index data along a route that passed mainly through ROFIs and mixed waters and only touched the southern bottom of the WIS seasonal gyre. It is certainly the case that the productive season in the WIS is comparatively short, in part because of the low water transparency. But the evidence cited earlier and more recent data reviewed suggest a complex interplay between the early life history stage of some fish, the physical oceanography of the Irish Sea and the onset and timing of the production season (DickeyCollas et al., 1996a; Beggs et al., 2014), with young fish moving from nursery grounds in Irish coastal waters to the WIS during its productive season. Furthermore, the sinking production from the Spring Bloom currently sustains a strong stock of Nephrops, and the fishery from this has largely replaced the harvest from pelagic and demersal fin-fisheries.

Changes in the abundance of predators seem likely to impact on plankton either directly (e.g., by reduction in the grazing pressure exerted by fish larvae) or indirectly (through consequences of the diversion of production from finfish to Nephrops). The changes observed in the Irish Sea are consistent with those found elsewhere when cod have been overfished. This was the case in the Scotia shelf on George's bank (Frank et al., 2005) where the regime shift let to a different fully functioning state. In the Irish Sea the shift to the Nephrops fishery is appreciated by the fishermen, because it is more lucrative than the fin fishery. 


\section{Change, Small Copepods, and Jellyfish}

Evidence for change over time in the WIS relates to copepods, jellyfish and commercial fisheries, and has consequences for our interpretations relating to GES and our synthesis of data obtained in different decades. The fisheries changes have already been discussed.

CPR data from the Irish Sea (Lynam et al., 2011) suggest a regime shift c. 1989, after which copepod biomass during the productive season was only about a third of what it had been previously, whereas the CPR "color index," used as a proxy for chlorophyll, showed a longer season with generally greater color, post-1989. However, these findings refer to the whole width of the Irish Sea between $53.25-53.75^{\circ} \mathrm{N}$, which includes the Liverpool Bay ROFI (in which elevated phytoplankton biomass has been linked to nutrient enrichment, Gowen et al., 2000) and the mixed central water as well as the WIS, and does not contradict our claims of no trend in phytoplankton or copepods since 1992 in the latter. In contrast to the CPR survey findings, our summary of observations of chlorophyll suggests a constant WIS climatology since 1968, although evidence from before 1992 is limited.

The same CPR line also sampled cnidarians. The data show large changes in their abundance since 1960 (Lynam et al., 2011). More precise data come from jellyfish sampled during the AFBI young fish surveys in May/June. There was a significant temporal trend, with jelly mass per haul more than doubling in WIS and adjacent Irish coastal waters over the 15 year sampling period (Lynam et al., 2011). Richardson et al. (2009) suggest that the causes of (apparently globally) increasing jellyfish abundance are overfishing, eutrophication, climate change, and import of alien species. The first three seem relevant to the Irish Sea as a whole.

Parsons (1979) contrasted the food web that linked diatom production efficiently to pelagic fish by way of large copepods such as Calanus, with a web that is in evolutionary terms much older, linking phytoflagellates to jellyfish by way of smaller pelagic grazers. It has been argued that a shift from "classical" food chains leading to commercial exploitable fish, to "jelly"dominated food chains is (a) a result of eutrophication and/or over-fishing (Tett and Mills, 1991; Lynam et al., 2011) and (b) is happening in many coastal seas (Purcell, 2012). Viewed in this light, the relative scarcity of Calanus, the dominance of WIS grazers by small copepods, including the cyclopoid Oithona, the relative abundance of heterotrophic protozoans in summer, the apparent increase in jellyfish, and the loss of top predators, might give cause for concern. However, the dominance of small copepods in most years may be a simple consequence of WIS hydrography: it is a small deep-water region which might be unsuitable for Calanus spp. For example, Calanus finmarchicus goes into diapause during winter and requires low temperature that the Irish Sea normally does not provide. The importance of ciliates and heterotrophic dinoflagellates may be better seen as evidence for a multivorous food web in the WIS. The jellyfish increase might be a result of climate change or of loss of specific jellyfish predators. It does not, so far, seem to have impacted on the pelagic habitat in the WIS.

\section{CONCLUSIVE DISCUSSION}

Our conclusion is that, on the basis of the findings summarized in Table 9, the pelagic habitat in the WIS is in GES. Justifying this evidence to conclusion requires establishing three main points. First, that the area we have studied in the WIS is indeed a discrete entity in respect of its pelagic subsystem. Second, that this entity can have a state that is either GES or not-GES. Third, that we have adequate evidence and a procedure for interpreting the evidence, to determine which of these states obtains. This section addresses those points, and, finally, the implications of our conclusion.

\section{Is the WIS a Distinct Entity?}

The definition of GES in MSFD Article 3.5(a) links it to "the structure, functions and processes of the constituent marine ecosystems" in a marine region or sub-region. Lindeman (1942) defines an ecosystem, as "the system composed of the physicalchemical-biological processes active within a space-time unit of any magnitude." The state of an arbitrarily-bounded system might however be difficult to establish, and our method therefore requires the system under study to be uniform in respect of ecohydrodynamic regime. The evidence shows that the WIS exists as a system with spatial boundaries naturally defined by bottom topography and the seasonal gyre, although open to "reset" in Winter by inflows from the North Atlantic and Irish coastal waters, and with a typical system-scale process closure time of a year. Thus, although it is only a small part of the Celtic Sea region that is the MSFD unit of reporting and management, the WIS pelagic ecosystem exists as a distinct system in the sense required for our assessment. Furthermore, the system has a distinct ecohydrodynamic regime that has been observed in all years studied and which (we've argued) drives the seasonal cycle. The regime falls in the "seasonally stratified" category although with several special features: early haline stratification aids early growth of phytoplankton, offsetting the high turbidity of these waters.

\section{How Is GES to Be Identified?}

Lindeman's definition of ecosystem is descriptive and open to different interpretations of the meaning of "the physicalchemical-biological processes" taking place therein. The textbook idea of an ecosystem is one of these interpretations. It has been pointed out (O'Neill, 2001) that "an ecosystem," as it is customarily understood, is not an observable but a construct, a way of organizing a set of observations. The paradigmatic example is the food web of the herring in the North Sea (Hardy, 1924), constructed from many observations of the stomach contents of fish and plankters.

The MSFD is also a conceptual structure, but it is a model of what should be rather than what is. It is intended to shape human behavior to achieve the objectives set out in the Directive's preamble. Within the MSFD, the idea of GES can be understood as both an objective assessment of the state of the relevant marine ecosystem-i.e., something arrived at independently of the Directive by the procedures of science-and a description of the state that European society wishes marine systems to reach, in order to ensure (MSFD Article 3.5) that "the use of 
TABLE 9 | Summary of conclusions relating to status at the study site WIS.

\begin{tabular}{|c|c|}
\hline Category & Conclusion \\
\hline Extent of the study region & $\begin{array}{l}\text { The region in the WIS that is in summer within the PEA contour for } 20 \mathrm{~J} \mathrm{~m}^{-3} \text { and which is within the cyclonic gyre } \\
\text { during stratification; a surface area of c } 3.5 \times 10^{3} \mathrm{~km}^{2} \text { and a total water volume of c } 3.15 \times 10^{11} \mathrm{~m}^{3} \text { given a mean } \\
\text { water depth of } 90 \mathrm{~m} \text {. }\end{array}$ \\
\hline Ecohydrodynamic type & $\begin{array}{l}\text { Euhaline temperate shelf water with thermal seasonal stratification April/May through September augmented by salinity } \\
\text { layering from February through May; however PAR attenuation is higher than in otherwise comparable seasonally } \\
\text { stratified shelf seas around Britain. }\end{array}$ \\
\hline Vigor: water chemistry (nutrients and oxygen) & $\begin{array}{l}\text { Winter nutrients 7:8:0.7 (N:Si:P, } \mu \mathrm{M}) \text { set mainly by Atlantic inflow with some enrichment from freshwater, balanced by } \\
\text { denitrification; SML June minima 0.8:1.5:0.5. N main limiting nutrient, possibly plus Si for diatoms in summer. Nutrients } \\
\text { within OSPAR limits. }\end{array}$ \\
\hline $\begin{array}{l}\text { Vigor: production (chlorophyll, primary } \\
\text { production, and pelagic-benthic coupling) }\end{array}$ & $\begin{array}{l}\text { Salinity contribution to stratification in winter does not result in earlier bloom, perhaps because of high PAR attenuation. } \\
\text { Gross photosynthesis c 200, net production c 100; new production c } 60 \mathrm{~g} \mathrm{C} \mathrm{m}^{-2} \mathrm{yr}^{-1} \text {. Spring Bloom provides major } \\
\text { productive pulse, divided between grazers and sedimentation to benthos. 10-20\% summer deoxygenation in deep } \\
\text { water due to remineralization beneath pycnocline. Production adequate for food web, and chlorophyll within OSPAR } \\
\text { limits; no eutrophication and no trend toward eutrophication. }\end{array}$ \\
\hline Organization: deduced trophic structure & $\begin{array}{l}\text { A fully functioning system with good functional response diversity at producer, grazer and predator levels. The usual } \\
\text { dominance of the Spring Bloom, by diatoms, feeds (mainly small) copepods, and ensures a food supply to the } \\
\text { benthos; subsequently the food web shifts to the more resilient multivorous type. The pelagic web is well linked to } \\
\text { higher trophic levels. It is unclear why large copepods are less abundant than expected in a SS regime, but this does } \\
\text { not seem to affect trophic transfers. }\end{array}$ \\
\hline Consequential aspects & $\begin{array}{l}\text { The pelagic habitat in the WIS provides good conditions for higher trophic levels, including sea-birds and the young of } \\
\text { commercially exploited fish and shellfish (Nephrops). There is no evidence of undesirable disturbance resulting from an } \\
\text { excess of vigor in the plankton (Tett et al., 2007). }\end{array}$ \\
\hline Counter-arguments & $\begin{array}{l}\text { The WIS is not completely isolated from adjacent, anthropogenically enriched, coastal waters. Large copepods (i.e., } \\
\text { Calanus) are less abundant than expected. There is evidence of change, from CPR data, in chlorophyll proxy, copepod } \\
\text { and jelly abundance, the latter supported by data from young fish surveys. However, CPR data includes other (and } \\
\text { more disturbed) ecohydrodynamic regimes. Overfishing has led to falls in stocks of main commercially exploited fish } \\
\text { and shift to Nephrops, which might be expected to impact on pelagic food web. }\end{array}$ \\
\hline
\end{tabular}

the marine environment is at a level that is sustainable, thus safeguarding the potential for uses and activities by current and future generations."

Bringing together the two parts-the assessment and the goal-is challenging (Mee et al., 2008; Borja et al., 2013, 2014; Tett et al., 2013). Although we have elsewhere proposed the Plankton Index (Tett et al., 2008; Gowen et al., 2015) as a quantitative tool for tracking change in pelagic community organization, it is not self-calibrating. In our view, there are no value-free methods for evaluating environmental status in relation to the MSFD or any other socially-determined framework for marine environmental protection. Furthermore, the arguments advanced above lead to the conclusion that the difference between not-GES and GES should not be seen as a threshold on a continuum of state. Instead, a status assessment is a judgment about certain deductions that can be made from available information; a marine ecosystem in GES is one that, according to present scientific knowledge, is likely to contribute to the socially desired purpose of ensuring good ecosystem health and sustainable ecosystem services; a non-GES system requires "programmes of measures" in order to achieve those purposes. The judgment is one that should be made holistically, on the balance of evidence, rather than by algorithmic aggregation of component indicators.

\section{Evidence and Assessment}

The evidence concerning the state of the WIS included vertical profiles of temperature, measurements of photosynthesis, counts of organisms contained in a water-sample or net haul, and so on, which we've analyzed according to the conceptual causal model in Figure $\mathbf{1}$ and the assessment scheme in Table 2. The scheme is explicitly informed by the criteria given in Commission Decision 2010/477/EU (2010), which expand the relevant qualitative descriptors $(1,4,5,6)$ of the MSFD. Implicitly, it assumes the existence of trophic transfers, which are evidenced by the gut contents data referred to in Section Observations of Zooplanktonic Predators concerning zooplankton predators, and by the experiments of Gowen et al. (1999) on copepod grazing.

On the basis of this and other evidence analyzed in Section Results and First-Order Discussion, we conclude that pelagic ecosystem vigor appears to be in balance with organization and with the system's capacity to channel production to higher trophic levels without undesirable disturbance. Although there is evidence of local human impact (in respect of fisheries effects on higher trophic levels, and in nutrient enrichment) and perhaps of the effects of climate change, these do not appear to have interfered with the organization and full-functioning of the pelagic ecosystem. Because the picture we have presented of pelagic ecosystem vigor and organization has been assembled from data taken over more than three decades, our synthesis relies on the absence of significant long-term trends. Gowen et al. $(2002,2008)$ show the absence of such trends in nutrients and phytoplankton during the 1990s and 2000s, but there is the counter-evidence of an increase in spring chlorophyll (Allen et al., 1998), and in scyphozoan jellyfish (Lynam et al., 2011). 
Nevertheless, we conclude that, on the balance of the evidence, it is more likely than not that the pelagic habitat in the WIS is in GES.

\section{Implications}

Since this conclusion was not algorithmically assembled, we cannot assign a quantitative uncertainty to our finding. It may be best understood in terms of its practical implication, which is that the planktonic component of the ecosystem (the pelagic habitat) is in a state to continue supplying services at the present level without additional management measures. Although, the WIS is only a small part of the Celtic Seas MSFD sub-region, it provides an ideal site for the continued monitoring of the pelagic habitat in relation to the supply of final ecosystem services, being already well-studied, and being comparatively sheltered and close to land. Thus, it could continue to provide a test case for the finding of GES.

Finally, as a next step in research related to monitoring of the pelagic habitat for the MSFD or for any other approach to maintaining a healthy state in marine ecosystems, observations from the WIS can be used to calibrate the Plankton Index (PI) tool. The WIS is in GES, therefore state space envelopes derived from recent plankton monitoring can be used as reference conditions in tracking change in the plankton community away from the desirable condition, whether in the WIS itself or in other sea-areas of similar ecohydrodynamic type.

\section{AUTHOR CONTRIBUTIONS}

CS, RG and PT all contributed substantially to the conception and design of the work, acquired, analyzed and interpreted data, drafted the work, and critically revised it for intellectual content. CS, RG, and PT gave final approval of the version to be published and agreed to be accountable for the aspects of the work in ensuring that questions are appropriately investigated and resolved. RG contributed substantially to the conception and design of the work. He acquired analyzed and interpreted data, drafted the work, and critically revised it for intellectual content. PT contributed substantially to the conception and design of the work. The acquisition and analysis of the data were his duty, to a lesser extent, while the interpretation of data, and drafting of the work while critically revising it for important intellectual content was his main impact.

\section{FUNDING}

The funding that supported the development of this work during sample collection, data analysis, and write-up came from: The EFF Project: Ecosystem Based Management of Irish Fisheries and other resources (CA/033766/11) funded through the Department of Agriculture and Rural Development (DARD). The lifeform and state space project (Defra 13580_ME5312) funded through the Department for Environment, Food and Rural Affairs (Defra). The NERC Innovations Research Grant (NE/M007855/1): The Lorn Pelagic Observatory, the Plankton Index, and the Marine Strategy Framework Directive: a Knowledge Exchange Proposal. The EPA project: Validating Biological Quality Elements (BQEs) for Tidal Freshwater Transitional Waters (TFTWs) in Ireland (2013-W-MS-15)

\section{ACKNOWLEDGMENTS}

The authors would like to thank the Department of Agriculture and Rural Development and the European Fishery Fund project (CA/033766/11) for making data available. Thank you also to Dr. Elisa Capuzzo for primary production and chlorophyll analysis in Figure 7 and to Mr. Brian Stewart for the collection and analysis of AFBI's unpublished data.

\section{REFERENCES}

Allen, J. R., Slinn, D. J., Shammon, T. M., Hartnoll, R. G., and Hawkins, S. J. (1998). Evidence for eutrophication of the Irish Sea over four decades. Limnol. Oceanogr. 43, 1970-1974. doi: 10.4319/lo.1998.43.8.1970

Alvarez-Cadena, J. N. (1993). Feeding of the chaetognath Sagitta elegans verrill. Estuar. Coast. Shelf Sci. 36, 195-206. doi: 10.1006/ecss.1993.1013

Armstrong, M. J. (1982). The predator-prey relationships of Irish Sea poor-cod (Trisopterus minutus L.), pouting (Trisopterus luscus L.), and cod (Gadus morhua L.). J. Conseil Permanent Int. l'Exploration Mer 40, 135-152. doi: 10. 1093/icesjms/40.2.135

Backhaus, J. O., Harms, I. H., Krause, M., and Heath, M. R. (1994). A hypothesis concerning the space-time succession of Calanus finmarchicus in the northern North Sea. ICES J. Mar. Sci. 51, 169-180. doi: 10.1006/jmsc.1994.1018

Bald, J., Borja, A., Muxika, I., Franco, J., and Valencia, V. (2005). Assessing reference conditions and physico-chemical status according to the European Water Framework Directive: a case-study from the Basque Country (Northern Spain). Mar. Pollut. Bull. 50, 1508-1522. doi: 10.1016/j.marpolbul.2005.06.019

Bassett, H. (1909). The flow of water through the Irish Sea. Lancs Sea Fish Lab Rep. 18, 148-157.

Bastian, T., Lilley, M. K. S., Beggs, S. E., Hays, G. C., and Doyle, T. K. (2014). Ecosystem relevance of variable jellyfish biomass in the Irish Sea between years, regions and water types. Estuar. Coast. Shelf Sci. 149, 302-312. doi: 10.1016/j. ecss. 2014.08 .018

Beardall, J., Fogg, G. E., Foster, P., Miller, I., Spencer, C. P., and Voltolina, D. (1978). Phytoplankton distributions in the western Irish Sea and Liverpool Bay and their relation to hydrological factors: a progress report. Biol. Contemp. 5, 163-175.

Beggs, S. E., Cardinale, M., Gowen, R. J., and Bartolino, V. (2014). Linking cod (Gadus morhua) and climate: investigating variability in Irish Sea cod recruitment. Fish. Oceanogr. 23, 54-64. doi: 10.1111/fog. 12043

Benedetti, F., Gasparini, S., and Ayata, S.-D. (2015). Identifying copepod functional groups from species functional traits. J. Plankton Res. 38, 159-166. doi: 10.1093/ plankt/fbv096

Blackford, J. C., Allen, J. I., and Gilbert, F. J. (2004). Ecosystem dynamics at six contrasting sites: a generic modelling study. J. Mar. Syst. 52, 191-215. doi: 10. 1016/j.jmarsys.2004.02.004

Boersma, M., Wiltshire, K. H., Kong, S.-M., Greve, W., and Renz, J. (2015). Longterm change in the copepod community in the southern German Bight. J. Sea Res. 101, 41-50. doi: 10.1016/j.seares.2014.12.004

Borja, Á., Dauer, D. M., and Grémare, A. (2012). The importance of setting targets and reference conditions in assessing marine ecosystem quality. Ecol. Indic. 12, 1-7. doi: 10.1016/j.ecolind.2011.06.018

Borja, A., Elloitt, M., Andersen, J. H., Cardoso, A. C., Carstensen, J., Ferreira, J. G., et al. (2013). Good environmental status of marine ecosystems: what is it and how do we know when we have attained it? Mar. Pollut. Bull. 76, 16-27. doi: 10. 1016/j.marpolbul.2013.08.042 
Borja, A., Prins, T., Simboura, N., Andersen, J. H., Berg, T., Marques, J. C., et al. (2014). Tales from a thousand and one ways to integrate marine ecosystem components when assessing the environmental status. Front. Mar. Sci. 1:72. doi: 10.3389/fmars.2014.00072

Bowden, K. F. (1950). Processes affecting the salinity of the Irish Sea. Geophys. J. Int. 6, 63-90. doi: 10.1111/j.1365-246X.1950.tb02983.x

Bowden, K. F. (1955). Physical oceanography of the Irish Sea. Ministry of agriculture fisheries and food. Fish. Invest. Ser. II, 18, 1-66.

Bowman, M. J., Esias, W. E., and Schnitzer, M. B. (1981). Tidal stirring and the distribution of phytoplankton in Long Island and Block Island Sounds. J. Mar. Res. 39, 587-603.

Brander, K. M., and Bennett, D. B. (1986). Interactions between Norway lobster Nephrops norvegicus, and cod (Gadus morhua) and their fisheries in the Irish Sea. Can. Special Publ. Fish. Aquat. Sci. 92, 269-281.

Brander, K. M., and Dickson, R. R. (1984). An Investigation of the Low Level of Fish Production in the Irish Sea. Vol. 183. Rapports et Proces-Verbaux des Reunions Conseil International pour l'Exploration de la Mer (ICES), 234-242.

Brito, A., Newton, A., Tett, P., and Fernandes, T. F. (2009). Sediment and water nutrients and microalgae in a coastal shallow lagoon, Ria Formosa (Portugal): implications for the Water Framework Directive. J. Environ. Monitor. 12, 318-328. doi: 10.1039/B909429F

Capuzzo, E., Painting, S. J., Forster, R. M., Greenwood, N., Stephens, D. T., and Mikkelsen, O. A. (2013). Variability in the sub-surface light climate at ecohydrodynamically distinct sites in the North Sea. Biogeochemistry 113, 85-103. doi: 10.1007/s10533-012-9772-6

Carboneras, C., Jutglar, F., and Kirwan, G. M. (2016). "Manx Shearwater (Puffinus puffinus)," in Handbook of the Birds of the World Alive, eds J. del Hoyo, A. Elliott, J. Sargatal, D. A. Christie, and E. de Juana (Barcelona: Lynx Edicions). Retrieved from: http://www.hbw.com/node/52573 (Accessed November 22, 2016).

Clements, F. E. (1916). "Development and structure of the biome," in Abstracts Ecological Society (Baltimore, MD: Carnegie Institute of Washington), 658.

Collins, M. A., De Grave, S., Lordan, C., Burnell, G. M., and Rodhouse, P. G. (1994). Diet of the squid Loligo forbesi Steenstrup (Cephalopoda: Loliginidae) in Irish waters. ICES J. Mar. Sci. 51, 337-344. doi: 10.1006/jmsc.1994.1034

Commission Decision 2010/477/EU (2010). Commission Decision of 1 September 2010 on criteria and methodological standards on good environmental status of marine waters (2010/477/EU). Off. J. Eur. Union L232, 14-24.

Conway, D. V. P., Coombs, S. H., and Smith, C. (1997). Vertical distribution of fish eggs and larvae in the Irish Sea and southern North Sea. ICES J. Mar. Sci. 54, 136-147. doi: 10.1006/jmsc.1996.0176

Coombes, S. H., Robins, D. B., Conway, D. V. P., Halliday, N. C., and Pomroy, A. J. (1994). Suspended particulates in the Irish Sea and feeding conditions for fish larvae. Mar. Biol. 118, 7-15. doi: 10.1007/BF00699214

Costanza, R. (1992). “Towards an operational definition of health," in Ecosystem Health - New Goals for Environmental Management, eds R. Costanza, B. Norton, and B. D. Haskell (Washington, DC: Island Press), 269.

Costanza, R., and Mageau, M. (1999). What is a healthy ecosystem? Aquat. Ecol. 33, 105-115. doi: 10.1023/A:1009930313242

Cugier, P., Billen, G., Guillaub, J. F., Garnier, J., and Ménesguen, A. (2005). Modelling the eutrophication of the Seine Bight (France) under historical, present and future riverine nutrient loading. J. Hydrol. 304, 381-396. doi: 10. 1016/j.jhydrol.2004.07.049

Cushing, D. H. (1969). The decline of the herring stocks and the gadoid outburst. Journal du Conseil Permanent International pour l'Exploration de la Mer, 39, $70-81$.

Cushing, D. H. (1989). A difference in structure between ecosystems in strongly stratified waters and in those that are only weakly stratified. J. Plankton Res. 11, 1-13. doi: 10.1093/plankt/11.1.1

Devlin, M. J., Barry, J., Mills, D. K., Gowen, R. J., Foden, J., Sivyer, D., et al. (2009). Estimating the diffuse attenuation coefficient from optically active constituents in UK marine waters. Estuar. Coast. Shelf Sci. 82, 73-83. doi: 10.1016/j.ecss. 2008.12.015

Diaz, R. J., and Rosenberg, R. (1995). Marine benthic hypoxia: a review of its ecological effects and the behavioural responses of benthic macrofauna. Oceanogr. Mar. Biol. 33, 245-303.

Dickey-Collas, M., Gowen, R. J., and Fox, C. J. (1996a). Distribution of larval and juvenile fish in the Western Irish Sea: relationship to phytoplankton, zooplankton biomass and recurrent physical features. Mar. Freshw. Res. 47, 169-181. doi: 10.1071/MF9960169

Dickey-Collas, M., Stewart, B. M., and Gowen, R. J. (1996b). The role of thermal stratification on the population dynamics of Sagitta elegans Verrill in the western Irish Sea. J. Plankton Res. 18, 1659-1674. doi: 10.1093/plankt/18.9.1659

Dickson, R. R., and Boelens, R. G. (1988). The Status of Current Knowledge on Anthropogenic Influence in the Irish Sea. ICES Cooperative Research Report, Vol. 155. ICES, Copenhagen.

Donohoe, H. M. (2011). A delphi toolkit for ecotourism research. J. Ecotour. 10, 1-20. doi: 10.1080/14724040903418897

Duarte, C. M., Conley, D. J., Carstensen, J., and Sánchez-Camacho, M. (2009). Return to neverland: shifting baselines affect eutrophication restoration targets. Estuar. Coasts 32, 29-36. doi: 10.1007/s12237-008-9111-2

Dugdale, R. C., and Goering, J. J. (1967). Uptake of new and regenerated forms of nitrogen in primary productivity. Limnol. Oceanogr. 12, 196-206. doi: 10.4319/ lo.1967.12.2.0196

Dussart, B. M. (1965). Les différentes catégories de plancton. Hydrobiologia 26, 72-74. doi: 10.1007/BF00142255

Edwards, M., Johns, D. G., Licandro, P., John, A. W. G., and Stevens, D. P. (2006). Ecological Status Report: Results from the CPR Survey 2004/2005. SAHFOS Technical Report, 3, Plymouth.

Elliott, M. E. (2011). Marine science and management means tackling exogenic unmanaged pressures and endogenic managed pressures - A numbered guide. Mar. Pollut. Bull. 62, 651-655. doi: 10.1016/j.marpolbul.2010.11.033

Escaravage, V., and Prins, T. C. (2002). Silicate availability, vertical mixing and grazing control of phytoplankton blooms in mesocosms. Hydrobiologia 484, 33-48. doi: 10.1023/A:1021344702895

Fernand, L., Weston, K., Morris, T., Greenwood, N., Brown, J., and Jickells, T. (2013). The contribution of the deep chlorophyll maximum to primary production in a seasonally stratified shelf sea, the North Sea. Biogeochemistry 113, 153-166. doi: 10.1007/s10533-013-9831-7

Figueiredo, G. M., Montagnes, D. J. S., and Nash, R. D. M. (2009). The importance of protozooplankton as prey for copepods in the coastal areas of the central Irish Sea. Hydrobiologia 628, 227-239. doi: 10.1007/s10750-009-9787-8

Fogg, G. E., Egan, B., Floodgate, G. D., Jones, D. A., Kassab, J. Y., Lochte, K., et al. (1985). Biological studies in the vicinity of a shallow-sea tidal mixing front VII. The frontal ecosystems. Philos. Trans. R. Soc. B 310, 555-571. doi: 10.1098/rstb. 1985.0131

Folke, C., Carpenter, S., Walker, B., Scheffer, M., Elmqvist, T., Gunderson, L., et al. (2004). Regime shifts, resilience, and biodiversity in ecosystem management. Annu. Rev. Ecol. Evol. Syst. 35, 557-581. doi: 10.1146/annurev.ecolsys.35. 021103.105711

Frank, K. T., Petrie, B., Choi, J. S., and Leggett, W. C. (2005). Trophic cascades in a formerly cod-dominated ecosystem. Science 308, 1621-1623. doi: 10.1126/ science. 1113075

Frederiksen, M., Harris, M. P., Daunt, F., Rothery, P., and Wanless, S. (2004). The role of industrial fisheries and oceanographic change in the decline of North Sea black-legged kittiwakes. J. Appl. Ecol. 41, 1129-1139. doi: 10.1111/j.00218901.2004.00966.x

Fromentin, J.-M., and Planque, B. (1996). Calanus and environment in the eastern North Atlantic. 11. Influence of the North Atlantic oscillation on C. finmarchicus and C. helgolandicus. Mar. Ecol. Prog. Ser. 134, 111-118. doi: 10. 3354/meps 134111

Gade, H. G., and Edwards, A. (1980). "Deep-water renewal in fjords," in Fjord Oceanography, eds H. F. Freeland, D. M. Farmer, and C. D. Levings (New York, NY: Plenum Press), 453-489.

Gibson, C. E. (ed.). (2011). Northern Ireland State of the Seas Report. Agri - Food and Bioscience Institute and Northern Ireland Enviroment Agency.

Gibson, C. E., Stewart, B. M., and Gowen, R. J. (1997). A synoptic study of nutrients in the north-western Irish Sea. Estuar. Coast. Mar. Sci. 45, 27-38. doi: 10.1006/ ecss.1996.0164

Gismervik, I. (2005). Numerical and functional responses of choreo- and oligotrich planktonic ciliates. Aquat. Microb. Ecol. 40, 163-173. doi: 10.3354/ame040163

Gismervik, I., Andersen, T., and Vadstein, O. (1996). Pelagic food webs and eutrophication of coastal waters: impact of grazers on algal communities. Mar. Pollut. Bull. 33, 22-35. doi: 10.1016/S0025-326X(96)00134-8

Gohin, F., Druon, J. N., and Lampert, L. (2002). A five channel chlorophyll concentration algorithm applied to SeaWiFS data processed by SeaDAS 
in coastal waters. Int. J. Remote Sens. 23, 1639-1661. doi: 10.1080/ 01431160110071879

Gowen, R. J., and Bloomfield, S. P. (1996). Chlorophyll standing crop and phytoplankton production in the western Irish Sea during 1992 and 1993. J. Plankton Res. 18, 1735-1751. doi: 10.1093/plankt/18.9.1735

Gowen, R. J., Collos, Y., Tett, P., Scherer, C., Bec, B., Abadie, E., et al. (2015). Response of diatom and dinoflagellate lifeforms to reduced phosphorus loading: a case study in the Thau lagoon, France. Estuar. Coast. Shelf Sci. 162, 45-52. doi: 10.1016/j.ecss.2015.03.033

Gowen, R. J., Dickey-Collas, M., and McCullough, G. (1997). The occurrence of Calanus finmarchicus (Gunnerus) and Calanus helgolandicus (Claus) in the western Irish Sea. J. Plankton Res. 19, 1175-1182. doi: 10.1093/plankt/19.8.1175

Gowen, R. J., Hydes, D. J., Mills, D. K., Stewart, B. M., Brown, J., Gibson, C. E., et al. (2002). Assessing trends in nutrient concentrations in coastal shelf seas: a case study in the Irish Sea. Estuar. Coast. Shelf Sci. 54, 927-939. doi: 10.1006/ ecss.2001.0849

Gowen, R. J., McCullough, G., Dickey-Collas, M., and Kleppel, G. S. (1998a). Copepod abundance in the western Irish Sea: relationship to physical regime, phytoplankton production and standing stock. J. Plankton Res. 20, 315-330. doi: $10.1093 /$ plankt/20.2.315

Gowen, R. J., McCullough, G., Kleppel, G. S., Houchin, L., and Elliott, P. (1999). Are copepods important grazers of the spring phytoplankton bloom in the western Irish Sea? J. Plankton Res. 21, 465-483. doi: 10.1093/plankt/21.3.465

Gowen, R. J., Mills, D. K., Trimmer, M., and Nedwell, D. B. (2000). Production and its fate in two coastal regions of the Irish Sea: the influence of anthropogenic nutrients. Mar. Ecol. Prog. Ser. 208, 51-64. doi: 10.3354/meps208051

Gowen, R. J., Raine, R., Dickey-Collas, M., and White, M. (1998b). Plankton distributions in relation to physical oceanographic features on the southern Malin Shelf, August 1996. ICES J. Mar. Sci. 55, 1095-1111. doi: 10.1006/jmsc. 1998.0418

Gowen, R. J., and Stewart, B. M. (2005). The Irish Sea: nutrient status and phytoplankton. J. Sea Res. 54, 36-50. doi: 10.1016/j.seares.2005.02.003

Gowen, R. J., Stewart, B. M., Mills, D. K., and Elliott, P. (1995). Regional differences in stratification and its effect on phytoplankton production and biomass in the north western Irish Sea. J. Plankton Res. 17, 753-769. doi: 10.1093/plankt/17. 4.753

Gowen, R. J., Tett, P., Bresnan, E., Davidson, K., McKinney, A., Harrison, P. J., et al. (2012). Anthropogenic nutrient enrichment and blooms of harmful phytoplankton. Oceanogr. Mar. Biol. 50, 65-126. doi: 10.1201/b12157-3

Gowen, R. J., Tett, P., and Jones, K. J. (1992). Predicting marine eutrophication: the yield of chlorophyll from nitrogen in Scottish coastal waters. Mar. Ecol. Prog. Ser. 85, 153-161. doi: 10.3354/meps085153

Gowen, R. J., Tett, P., Kennington, K., Mills, D. K., Shammon, T. M., Stewart, B. M., et al. (2008). The Irish Sea: is it eutrophic? Estuar. Coast. Shelf Sci. 76, 239-254. doi: 10.1016/j.ecss.2007.07.005

Gowen, R. J., Tett, P., and Smayda, T. J. (2013). Phytoplankton and the balance of nature: an opinion. Estuar. Coast. Shelf Sci. 113, 317-323. doi: 10.1016/j.ecss. 2012.08.009

Habermas, J. (1984). The Theory of Communicative Action. Vol. 1: Reason and the Rationalization of Society. Boston, MA; Cambridge, UK: Beacon Press; Polity Press.

Halpern, B. S., Walbridge, S., Selkoe, K. A., Kappel, C. V., Micheli, F., D’Agrosa, C., et al. (2008). A global map of human impact on marine ecosystems. Science 319, 948-952. doi: 10.1126/science.1149345

Halsband, C., and Hirche, H. J. (2001). Reproductive cycles of dominant calanoid copepods in the North Sea. Mar. Ecol. Prog. Ser. 209, 219-229. doi: 10.3354/ meps209219

Hansen, P. J., and Calado, A. J. (1999). Phagotrophic mechanisms and prey selection in free-living dinoflagellates. J. Eurkaryot. Microbiol. 46, 382-389.

Hardy, A. C. (1924). The herring in relation to its animate environment. Part I. The food and feeding habits of the herring with special reference to the east coast of England. Fish. Invest. Ser. II 7, 1-53.

HELCOM (2015). HELCOM Eutrophication Assessment Manual (updated 2015). Available online at: http://www.helcom.fi/Documents/Eutrophication \%20assessment\%20manual.pdf\#search=concentration\%20thresholds

Hensley, R. T. (1996). A preliminary survey of the benthos from the Nephrops norvegicus mud grounds in the north-western Irish Sea. Estuar. Coast. Shelf Sci. 42, 457-465. doi: 10.1006/ecss.1996.0029
Herdman, W. A. (1918). The distribution of certain Diatoms and Copepods, throughout the year, in the Irish Sea. J. Linnean Soc. XlIV, 173-204.

Herman, A. W., and Platt, T. (1986). Primary production profiles in the ocean: estimation from a chlorophyll/light model. Oceanol. Acta 9, 31-40.

Hill, A. E., Brown, J., and Fernand, L. (1996). The western Irish Sea gyre: a retention mechanism for the Norway lobster (Nephrops norvegicus)? Oceanol. Acta 19, 357-368.

Hill, A. E., Brown, J., and Fernand, L. (1997). The summer gyre in the Western Irish Sea: shelf sea paradigms and management implications. Estuar. Coast. Shelf Sci. 44, 83-95. doi: 10.1016/S0272-7714(97)80010-8

Hill, A. E., Brown, J., Fernand, L., Holt, J., Horsburgh, K. J., Proctor, R., et al. (2008). Thermohaline circulation of shallow tidal seas. Geophys. Res. Lett. 35, L11605, doi: 10.1029/2008gl033459

Hill, A. E., Durazo, R., and Smeed, D. A. (1994). Observations of a cyclonic gyre in the western Irish Sea. Cont. Shelf Res. 14, 479-490 doi: 10.1016/02784343(94)90099-x

Hill, J. M. (2007). Structure and Flow of Carbon and Nitrogen to the Western Irish Sea Nephrops norvegicus: A Stable Isotope Approach. Ph.D. thesis, School of Biological and Chemical Sciences, Queen Mary, University of London, 1-262.

Hirsch, R. M., Alexander, R. B., and Smith, R. A. (1991). Selection of methods for the detection and estimation of trends in water quality. Water Resour. Res. 27, 803-813. doi: 10.1029/91WR00259

Hirsch, R. M., and Slack, J. R. (1984). A nonparametric trend test for seasonal data with serial dependence. Water Resour. Res. 20, 727-732. doi: 10.1029/ WR020i006p00727

Holt, J. T., and Proctor, R. (2003). The role of advection in determining the temperature structure of the Irish Sea. J. Phys. Oceanogr. 33, 2288-2306. doi: 10. 1175/1520-0485(2003)033<2288:TROAID>2.0.CO;2

Horsburgh, K. J., Hill, A. E., Brown, J., Fernand, L., Garvine, R. W., and Angelico, M. M. P. (2000). Seasonal evolution of the cold pool gyre in the western Irish Sea. Prog. Oceanogr. 46, 1-58. doi: 10.1016/S0079-6611(99)00054-3

Hughes, T. P., Bellwood, D. R., Folke, C., Steneck, R. S., and Wilson, J. (2005). New paradigms for supporting the resilience of marine ecosystems. Trends Ecol. Evol. 20, 380-386. doi: 10.1016/j.tree.2005.03.022

Hydes, D. J., Gowen, R. J., Holliday, N. P., Shammon, T., and Mills, D. (2004). External and internal control of winter concentrations of nutrients (N, P and Si) in north-west European shelf seas. Estuar. Coast. Shelf Sci. 59, 151-161. doi: 10. 1016/j.ecss.2003.08.004

Hydes, D. J., Kelly-Gerreyn, B. A., Le Gall, A. C., and Proctor, R. (1999). The balance of supply of nutrients and demands of biological production and denitrification in a temperate latitude shelf sea - a treatment of the southern North Sea as an extended estuary. Mar. Chem. 68, 117-131. doi: 10.1016/S03044203(99)00069-9

ICES Ecosystem overview (2016). Celtic Seas Ecolregions - Ecosystem Overview. Available online at: http://www.ices.dk/sites/pub/Publication\%20Reports/ Advice/2016/2016/Celtic_Sea_Ecoregion-Ecosystem_overview.pdf (Accessed June 15, 2016).

JNCC (2015). Seabird Population Trends and Causes of Change: 1986-2014 Report. Joint Nature Conservation Committee. Available online at: http://www.jncc. defra.gov.uk/page-3201 (Accessed March 3, 2016).

Joint, I., and Pomroy, A. (1993). Phytoplankton biomass and production in the southern North Sea. Mar. Ecol. Progr. Ser. 99, 169-182. doi: 10.3354/ meps099169

Jones, K. J., and Gowen, R. J. (1990). Influence of stratification and irradiance regime on summer phytoplankton composition in coastal and shelf seas of the British Isles. Estuar. Coast. Shelf Sci. 30, 557-567. doi: 10.1016/02727714(90)90092-6

Kaiser, M. J., Clarke, K. R., Hinz, H., Austen, M. C. V., Somerfield, P. J., and Karakassis, I. (2006). Global analysis of response and recovery of benthic biota to fishing. Mar. Ecol. Prog. Ser. 311, 1-14. doi: 10.3354/meps311001

Kelly, C. J., Codling, E. A., and Rogan, E. (2006). The Irish Sea cod recovery plan: some lessons learned. ICES J. Mar. Sci. 63, 600-610. doi: 10.1016/j.icesjms.2005. 12.001

Kenny, A. J., Skjoldal, H. R., Engelhard, G. H., Kershaw, P. J., and Reid, J. B. (2009). An integrated approach for assessing the relative significance of human pressures and environmental forcing on the status of Large Marine Ecosystems. Prog. Oceanogr. 81, 132-148. doi: 10.1016/j.pocean.2009. 04.007 
Kiørboe, T. (2011). How zooplankton feed: mechanisms, traits and trade-offs. Biol. Rev. 86, 311-339. doi: 10.1111/j.1469-185X.2010. 00148.x

Kirkwood, D. (1996). "Nutrients: practical notes on their determination in sea water," in ICES Techniques in Marine Environmental Sciences, ICES 6th Intercomparison (Suffolk: MAFF Fisheries Laboratory).

Lacroix, G., Ruddick, K., Gypens, N., and Lancelot, C. (2007). Modelling the relative impact of rivers (Scheldt/Rhine/Seine) and Western Channel waters on the nutrient and diatoms/Phaeocystis distributions in Belgian waters (Southern North Sea). Cont. Shelf Res. 27, 1422-1446. doi: 10.1016/j.csr.2007.01.013

Lalli, C. M., and, Parsons, T. R. (1997). Biological Oceanography: An Introduction. Oxford: Elsevier Butterworth-Heinemann.

Lancelot, C., Rousseau, V., and Gypens, N. (2009). Ecologically based indicators for Phaeocystis disturbance in eutrophied Belgian coastal waters (Southern North Sea) based on field observations and ecological modelling. J. Sea Res. 61, 44-49. doi: 10.1016/j.seares.2008.05.010

Lassen, H., Pedersen, S. A., Frost, H., and A., H. (2013). Fishery management advice with ecosystem considerations. ICES J. Mar. Sci. 70, 471-479. doi: 10. 1093/icesjms/fss208

Lee, J.-Y., Tett, P., Jones, K., Jones, S., Luyten, P., Smith, C., et al. (2002). The PROWQM physical-biological model with benthic-pelagic coupling applied to the northern North Sea. J. Sea Res. 48, 287-331. doi: 10.1016/S1385$1101(02) 00182-X$

Lee, J.-Y., Tett, P., and Kim, K.-R. (2003). Parameterising a microplankton model. J. Kor. Soc. Oceanogr. 38, 185-210.

Legendre, L., and Rassoulzadegan, F. (1995). Plankton and nutrient dynamics in marine waters. Ophelia 41, 153-172. doi: 10.1080/00785236.1995.10422042

Levitus, S. (1982). Climatological Atlas of the World Ocean. Washington, DC: US Government Printing Office.

Lindeman, R. A. (1942). The trophic-dynamic aspect of ecology. Ecology 23, 399-417. doi: 10.2307/1930126

Linstone, H. A., and Turoff, M. (eds.). (2002). The Delphi Method: Techniques and Applications. Newark, NJ: New Jersey Institute of Technology.

Lynam, C. P., Lilley, M. K. S., Bastian, T., Doyle, T. K., Beggs, S. E., and Hays, G. C. (2011). Have jellyfish in the Irish Sea benefited from climate change and overfishing? Glob. Chang. Biol. 17, 767-782. doi: 10.1111/j.1365-2486.2010. 02352.x

Lynn, D. H. (2003). Morphology or molecules: how do we identify the major lineages of ciliates (Phylum Ciliophora)? Eur. J. Protistol. 39, 356-364. doi: 10. 1078/0932-4739-00004

MacKey, M., and Giménez, D. P. (2004). SEA 678 Data Report for Offshore Seabird Populations. A Report for the DTI, 56. Available online at: https://www.gov.uk/ government/uploads/system/uploads/attachment_data/file/197026/SEA678_ Seabirds.pdf

Mageau, M. T., Costanza, R., and Ulanowicz, R. E. (1995). The development and initial testing of a quantitative assessment of ecosystem health. Ecosyst. Health $1,201-213$.

Margalef, R. (1967). The food web in pelagic environment. Helgoländer Wissenschaftliche Meeresuntersuchungen 15, 548-559. doi: 10.1007/ BF01618650

Margalef, R. (1978). Life forms of phytoplankton as survival alternatives in an unstable environment. Oceanol. Acta 1, 493-509.

Marine Strategy Framework Directive (2008). Directive 2008/56/EC of the European Parliament and of the Council of 17 June 2008 establishing a framework for community action in the field of marine environmental policy. Off. J. Eur. Union L164, 19-40.

Marshall, S. M., and Orr, A. P. (1927). The relation of the plankton to some chemical and physical factors in the Clyde Sea area. J. Mar. Biol. Assoc. UK 14, 837-868. doi: 10.1017/S0025315400051110

Matthews, D. J. (1914). The salinity and temperature of the Irish Channel and the waters south of Ireland. Fish. Irel. Sci. Invest. 4, 26.

McKinney, E. S. A., Gibson, C. E., and Stewart, B. M. (1997). Planktonic diatoms in the North-West Irish Sea: a study by automatic sampler. Biol. Environ. 97, 197-202.

Mee, L. D., Jefferson, R. L., Laffoley, D. D. A., and Elliott, M. (2008). How good is good? Human values and Europe's proposed Marine Strategy Directive. Mar. Pollut. Bull. 56, 187-204. doi: 10.1016/j.marpolbul.2007. 09.038
Mitra, A., Castellani, C., Gentleman, W. C., Jónasdóttir, S. H., Flynn, K. J., Bode, A., et al. (2014). Bridging the gap between marine biogeochemical and fisheries sciences: configuring the zooplankton link. Prog. Oceanogr. 129, 176-199. doi: $10.1016 /$ j.pocean.2014.04.025

Mitson, R. B., Simard, Y., and Goss, C. (1996). Use of a two-frequency algorithm to determine size and abundance of plankton in three widely spaced locations. ICES J. Mar. Sci. 53, 209-215. doi: 10.1006/jmsc. 1996.0024

Morán, X. A. G., López-Urrutia, Á., Calvo-Díaz, A., and Li, W. K. W. (2010). Increasing importance of small phytoplankton in a warmer ocean. Glob. Chang. Biol. 16, 1137-1144. doi: 10.1111/j.1365-2486.2009.01960.x

Moschonas, G., Gowen, R. J., Stewart, B. M., and Davidson, K. (2016). Nitrogen dynamics in the Irish Sea and adjacent shelf waters: an exploration of dissolved organic nitrogen. Estuar. Coast. ShelfSci. 164, 276-287. doi: 10.1016/j.ecss.2015. 07.030

Nash, R. D. M., and Geffen, A. J. (2004). Seasonal and interannual variation in abundance of Calanus finmarchicus (Gunnerus) and Calanus helgolandicus (Claus) in inshore waters (west coast of the Isle of Man) in the central Irish Sea. J. Plankton Res. 26, 265-273. doi: 10.1093/plankt/fbh029

Nedwell, D. B., Dong, L. F., Sage, A., and Underwood, G. J. C. (2002). Variations of the nutrient loads to the mainland U.K. estuaries: correlation with catchment areas, urbanisation and coastal eutrophication. Estuar. Coast. Shelf Sci. 54, 951-970. doi: 10.1006/ecss.2001.0867

Nihoul, J. C. J. (ed.). (1981). "Ecohydrodynamics," in Proceedings of the 12th International Liège Colloqium on Ocean Hydrodynamics (Amsterdam: Elsevier Scientific Publishing Company).

Ojaveer, H., and Eero, M. (2011). Methodological challenges in assessing the environmental status of a marine ecosystem: case study of the Baltic Sea. PLoS ONE 6:e19231. doi: 10.1371/journal.pone.0019231

O'Neill, R. V. (2001). Is it time to bury the ecosystem concept? (with full military honors, of course!). Ecology 82, 3275-3284. doi: 10.1890/00129658(2001)082[3275:IITTBT]2.0.CO;2

OSPAR COMMISSION (2003). OSPAR Integrated Report 2003 on the Eutrophication Status of the OSPAR Maritime Area Based Upon the First Application of the Comprehensive Procedure. OSPAR Commission.

OSPAR COMMISSION (2005). Ecological Quality Objectives for the Greater North Sea with Regard to Nutrients and Eutrophication Effects. OSPAR Background Document on Eutrophication, 2005/229, OSPAR.

Österblom, H., Hansson, S., Larsson, U., Hjerne, O., Wulff, F., Elmgen, R., and Folke, C. (2007). Human-induced trophic cascades and ecological regime shifts in the Baltic Sea. Ecosystems 10, 877-889. doi: 10.1007/s10021-0079069-0

Parsons, T. R. (1979). Some ecological, experimental and evolutionary aspects of the upwelling ecosystem. S. Afr. J. Sci. 75, 536-540.

Pingree, R. D., and Griffiths, D. K. (1978). Tidal fronts on the shelf seas around the British Isles. J. Geophys. Res. 83, 4615-4622. doi: 10.1029/JC083iC09p04615

Pingree, R. D., Holligan, P. M., and Mardell, J. (1978). The effects of vertical stability on phytoplankton distributions in the summer on the north western European shelf. Deep Sea Res. 25, 1011-1028. doi: 10.1016/01466291(78)90584-2

Platt, T., and Sathyendranath, S. (2008). Ecological indicators for the pelagic zone of the ocean from remote sensing. Remote Sens. Environ. 112, 3426-3436. doi: 10.1016/j.rse.2007.10.016

Purcell, J. E. (2012). Jellyfish and ctenophore blooms coincide with human proliferations and environmental perturbations. Ann. Rev. Mar. Sci. 4, 209-235. doi: 10.1146/annurev-marine-120709-142751

Queste, B. Y., Fernand, L., Jickells, T. D., and Heywood, K. J. (2013). Spatial extent and historical context of North Sea oxygen depletion in August 2010. Biogeochemistry 113, 53-68. doi: 10.1007/s10533-012-9729-9

Raven, J. A. (1998). The twelfth Tansely lecture. Small is beautiful: the picophytoplankton. Funct. Ecol., 12, 503-513. doi: 10.1046/j.1365-2435.1998. 00233.x

Richardson, A. J., Bakun, A., Hays, G. C., and Gibbons, M. J. (2009). The jellyfish joyride: causes, consequences and management responses to a more gelatinous future. Trends Ecol. Evol. 24, 312-322. doi: 10.1016/j.tree.2009. 01.010

Richardson, K., Lavin-Peregrina, M. F., Mitchelson, E. G., and Simpson, J. H. (1985). Seasonal distribution of chlorophyll-a in relation to physical structure in the western Irish Sea. Oceanol. Acta 8, 77-86. 
Rippeth, T. P., Lincoln, B. J., Kennedy, H. A., Palmer, M. R., Sharples J., and Williams, C. A. J. (2014). Impact of vertical mixing on sea surface $\mathrm{pCO}_{2}$ in temperate seasonally stratified shelf seas. J. Geophys. Res. 119, 3868-3882. doi: 10.1002/2014JC010089

Rippeth, T. P., Wiles, P., Palmer, M. R., Sharples J, and Tweddle, J. (2009). The diapcynal nutrient flux and shear-induced diapcynal mixing in the seasonally stratified western Irish Sea. Cont. Shelf Res. 29, 1580-1587. doi: 10.1016/j.csr. 2009.04.009

Ryther, J. H., and Dunstan, W. M. (1971). Nitrogen, phosphorus, and eutrophication in the coastal marine environment. Science 171, 1008-1013. doi: $10.1126 /$ science.171.3975.1008

Scherer, C. (2012). Developing and Testing an Index of Change in Microplankton Community Structure in Temperate Shelf Seas. Ph.D. thesis, Edinburg Napier University, Scotland.

Scherer, C., Gowen, R., Tett, P., Atkinson, A., Baptie, M., Best, M., et al. (2014). Development of a UK Integrated Plankton Monitoring Programme. A Final Report of the Lifeform and State Space Project for Defra. The Department of Environment, Food and Rural Affairs, London.

Scherer, C., and Gowen, R. J. (2013). Determining the Status of the Microplankton Community in the Western Irish Sea. A report to the Department of Agriculture and Rural Developments (DARD), 76.

Scott, A. (1907). Report on the tow-nettings. Proc. Liverpool Biol. Soc. XXI, $137-190$.

Scrope-Howe, S., and Jones, D. A. (1985). Biological studies in the vicinity of a shallow-sea tidal mixing front V. composition, abundance and distribution of zooplankton in the Western Irish Sea, April 1980 to November 1981. Philos. Trans. R. Soc. B 310, 501-519. doi: 10.1098/rstb.1985.0129

Service, M., and Magorrian, B. H. (1997). The extent and temporal variation of disturbance to epibenthic communities in Strangford Lough, Northern Ireland. J. Mar. Biol. Assoc. UK 77, 1151-1164. doi: 10.1017/S0025315400038686

Sieburth, J. M., Smetacek, V., and Lenz, J. (1978). Pelagic ecosystem structure: heterotrophic compartments of the plankton and their relationship to plankton size fractions. Limnol. Oceanogr. 23, 1256-1263. doi: 10.4319/lo.1978.23. 6.1256

Simpson, J. H. (1997). Physical processes in the ROFI regime. J. Mar. Syst. 12, 3-15. doi: 10.1016/S0924-7963(96)00085-1

Simpson, J. H., Allen, C. M., and Morris, N. C. G. (1978). Fronts on the continental shelf. J. Geophys. Res. 83, 4607-4614. doi: 10.1029/JC083iC09p04607

Simpson, J. H., and Hunter, J. R. (1974). Fronts in the Irish Sea. Nature 250, 4040-4406. doi: 10.1038/250404a0

Simpson, J. H., and Rippeth, T. P. (1998). Non-conservative nutrient fluxes from budgets for the Irish Sea. Estuar. Coast. Shelf Sci. 47, 707-714. doi: 10.1006/ecss. 1998.0394

Slinn, D. J. (1974). Water circulation and nutrients in the North-west Irish Sea. Estuar. Coast. Mar. Sci. 2, 1-25. doi: 10.1016/0302-3524(74)90024-3

Smayda, T. J. (1980). "Phytoplankton species succession,” in The Physiological Ecology of Phytoplankton, ed I. Morris (Oxford: Blackwell), 493-570.

Smetacek, V., and Passow, U. (1990). Spring bloom initiation and Sverdrup's critical depth model. Limnol. Oceanogr. 35, 228-234. doi: 10.4319/lo.1990.35. 1.0228

Spencer, M., Birchenough, S. N. R., Mieszkowska, N., Robinson, L. A., Simpson, S. D., Burrow, M. T., et al. (2011). Temporal change in UK marine communities: trends or regime shifts? Mar. Ecol. 32, 10-24. doi: 10.1111/j.1439-0485.2010. 00422.x

Strickland, J. D. H., and Parsons, T. R. (1967). A practical handbook of seawater analysis. Bull. Fish. Res. Board Can. 167, 310.

Strickland, J. D. H., and Parsons, T. R. (eds). (1968). "Determination of dissolved oxygen," in A Practical Handbook of Seawater Analysis, Bulletin 167 (Ottawa, ON: Fisheries Research Board of Canada), 71-75.

Suess, E., and Müller, P. J. (1980). Productivity, Sedimentation Rate and Sedimentary Organic Matter in the Oceans. 2. Elemental Fractionation. Biogéochimie de la matiére organique a l'interface eau-sediment marin. Colloquim Internationale CNRS, 17-26.

Sverdrup, H. U. (1953). On conditions for the vernal blooming of phytoplankton. J. Conseil 18, 237-295. doi: 10.1093/icesims/18.3.287

Talling, J. F. (1971). The underwater light climate as a controlling factor in the production ecology of freshwater phytoplankton. Mitteilungen Int. Vereinigung Limnol. 19, 214-243.
Tarling, G. A., Ensor, N. S., Fregin, T., Goodall-Copestake, W. P., and Fretwell, P. (2010). "Chapter one - an introduction to the biology of Northern Krill (Meganyctiphanes norvegica Sars)," in Advances in Marine Biology, ed G. A. Tarling (Oxford, UK: Academic Press), 1-40.

Tett, P. (1990). "The photic zone," in Light and Life in the Sea (1st Annual Scientific Meeting of the Marine Biological Association), eds P. J. Herring, A. K. Campbell, M. Whitfield, and L. Maddock (Plymouth: Cambridge University Press), 59-87.

Tett, P., Carreira, C., Mills, D., Van Leeuwen, S., Foden, J., Bresnan, E., et al. (2008). Use of a Phytoplankton Community Index to assess the health of coastal waters. ICES J. Mar. Sci. 65, 1475-1482 doi: 10.1093/icesjms/ fsn 161

Tett, P., Gowen, R., Mills, D., Fernandes, T., Gilpin, L., Huxham, M., et al. (2007). Defining and detecting undesirable disturbance in the context of eutrophication. Mar. Pollut. Bull. 53, 282-297. doi: 10.1016/j.marpolbul.2006. 08.028

Tett, P., Gowen, R., Painting, S., Elliott, M., Forster, R., Mills, D., et al. (2013). A framework for understanding marine ecosystem health. Mar. Ecol. Prog. Ser. 494, 1-27. doi: 10.3354/meps10539

Tett, P., Joint, I., Purdie, D., Baars, M., Oosterhuis, S., Daneri, G., et al. (1993). Biological consequences of tidal stirring gradients in the North Sea. Philos. Trans. R. Soc. Lond. A, 340, 493-508. doi: 10.1098/rsta.1993.0061

Tett, P., and Mills, D. (1991). The plankton of the North Sea - pelagic ecosystems under stress? Ocean Shoreline Manag. 16, 233-257. doi: 10.1016/ 0951-8312(91)90006-N

Tett, P., and Wilson, H. (2000). From biogeochemical to ecological models of marine microplankton. J. Mar. Syst. 25, 431-446. doi: 10.1016/S09247963(00)00032-4

Tett, P. B. (1969). Marine Bioluminescence. Ph.D. thesis, University of Glasgow.

Tett, P. B. (1987). Modelling the growth and distribution of marine microplankton. Soc. Gen. Microbiol. Symp. 41, 387-425.

Tett, P. B., and Droop, M. R. (1988). "Cell quota models and planktonic primary production," in Handbook of Laboratory Model Systems for Microbial Ecosystems, ed J. W. T. Wimpenny (Florida: CRC Press), 177-220.

Tett, P. B. L., Gilpin, H., Svendsen, C., Erlandsson, P., Larsson, U., Scory, S., et al. (2003). Eutrophication and some European waters of restricted exchange. Cont. Shelf Res. 23, 1635-1671. doi: 10.1016/j.csr.2003.06.013

Thurstan, R. H., Brockington, S., and Roberts, C. M. (2010). The effects of 118 years of industrial fishing on UK bottom trawl fisheries. Nat. Commun. 1:15 doi: 10 . 1038/ncomms1013

Trimmer, M., Gowen, R. J., and Stewart, B. M. (2003). Changes in sediment processes across the western Irish Sea front. Estuar. Coast. Shelf Sea Sci. 53, 1011-1019. doi: 10.1016/S0272-7714(02)00312-8

Trimmer, M., Gowen, R. J., Stewart, B. M., and Nedwell, D. B. (1999). The spring bloom and its impact on benthic mineralisation rates in western Irish Sea sediments. Mar. Ecol. Progr. Ser. 185, 37-46. doi: 10.3354/meps 185037

Utermöhl, H. (1958). Zur Vervollkommung der quantitativen PhytoplanktonMethodik. Mitteilungen Internationale Vereinigung fuer Limnologie, 9, 1-38. UWWTD 91/271/EC, Urban Waste Water Treatment Directive.

Van der Molen, J., Aldridge, J. N., Coughlan, C., Parker, E. R., Stephens, D., and Ruadij, P. (2013). Modelling marine ecosystem response to climate change and trawling in the North Sea. Biogeochemistry 113, 213-236. doi: 10.1007/s10533012-9763-7

Van Leeuwen, S., Tett, P., Mills, D., and van der Molen, J. (2015). Stratified and non-stratified areas in the North Sea: Long-term variability and biological and policy implications. J. Geophys. Res. 120, 4670-4686. doi: 10.1002/ 2014JC010485

Vincent, M. A., Atkins, S. M., Lumb, C. M., Golding, N., Lieberknecht, L. M., and Webster, M. (2004). Marine Nature Conservation and Sustainable Development - The Irish Sea Pilot. Report to Defra by the Joint Nature Conservation Committee, Peterborough, ON.

Von Bertalanffy, L. (1972). The history and status of general systems theory. Acad. Manage. J. 15, 407-426. doi: 10.2307/255139

Wanless, S., Frederiksen, M., Daunt, F., Scott, B. E., and Harris, M. P. (2007) Black-legged kittiwakes as indicators of environmental change in the North Sea: evidence from long-term studies. Prog. Oceanogr. 72, 30-38. doi: 10.1016/ j.pocean.2006.07.007 
Weeks, A., and Simpson, J. H. (1990). The measurement of suspended particulate concentrations from remotely-sensed data. Int. J. Remote Sens. 12, 725-737.

Weeks, A. R., Simpson, J. H., and Bowers, D. (1993). The relationship between concentrations of suspended particulate material and tidal processes in the Irish Sea. Cont. Shelf Res. 13, 1325-1334. doi: 10.1016/0278-4343(93)90086-D

Wesche, A., Wiltshire, K. H., and Hirche, H. J. (2007). Overwintering strategies of dominant calanoid copepods in the German Bight, southern North Sea. Mar. Biol. 151, 1309-1320. doi: 10.1007/s00227-006-0560-5

WFD (2000). Directive 2000/60/EC of the European Parliament and of the Council of 23 October 2000 establishing a framework for Community action in the field of water policy. Off. J. Eur. Union L327, 1-72.

White, R. G., Hill, A. E., and Jones, D. A. (1988). Distribution of Nephrops norvegicus (L.) larvae in the western Irish Sea, an example of advective control of recruitment. J. Plankton Res. 10, 735-747. doi: 10.1093/plankt/10.4.735

Williams, C., Sharples, J., Green, M., Mahaffey, C., and Rippeth, T. (2013). The maintenance of the subsurface chlorophyll maximum in the stratified western Irish Sea. Limnol. Oceanogr. 3, 61-73. doi: 10.1215/21573689-22 85100

Williams, R., Conway, D. V. P., and Hunt, H. G. (1994). The role of copepods in the planktonic ecosystems of mixed and stratified waters of the European shelf seas. Hydrobiologia 292-293, 521-530. doi: 10.1007/BF00229980
Williamson, D. I. (1952). Distribution of plankton in the Irish Sea in 1949 and 1950. Proc. Trans. Liverpool Biol. Soc. 58, 1-46.

Williamson, D. I. (1956). The plankton in the Irish Sea, 1951 and 1952. Bull. Mar. Ecol. 4, 87-114.

Woodward, F. I., Lomas, M. R., and Kelly, C. K. (2004). Global climate and the distribution of plant biomes. Philos. Trans. R. Soc. 359, 1465-1476. doi: 10.1098/ rstb.2004.1525

Zwolsman, J. J. G. (1994). Seasonal variability and biogeochemistry of phosphorus in the Scheldt estuary, SW Netherlands. Estuar. Coast. Shelf Sci. 39, 227-248. doi: $10.1006 /$ ecss.1994.1061

Conflict of Interest Statement: The authors declare that the research was conducted in the absence of any commercial or financial relationships that could be construed as a potential conflict of interest.

Copyright (C) 2016 Scherer, Gowen and Tett. This is an open-access article distributed under the terms of the Creative Commons Attribution License (CC BY). The use, distribution or reproduction in other forums is permitted, provided the original author(s) or licensor are credited and that the original publication in this journal is cited, in accordance with accepted academic practice. No use, distribution or reproduction is permitted which does not comply with these terms. 